Article

\title{
Analyzing and Predicting Land Use and Land Cover Changes in New Jersey Using Multi-Layer Perceptron-Markov Chain Model
}

\author{
Kikombo Ilunga Ngoy *, Feng Qi and Daniela J. Shebitz
}

check for updates

Citation: Ngoy, K.I.; Qi, F.;

Shebitz, D.J. Analyzing and

Predicting Land Use and Land Cover

Changes in New Jersey Using

Multi-Layer Perceptron-Markov

Chain Model. Earth 2021, 2, 845-870.

https: / / doi.org/10.3390/earth2040050

Academic Editor: Ioannis Gitas

Received: 21 September 2021

Accepted: 27 October 2021

Published: 3 November 2021

Publisher's Note: MDPI stays neutral with regard to jurisdictional claims in published maps and institutional affiliations.
School of Environmental and Sustainability Sciences, Kean University, Union, NJ 07083, USA; fqi@kean.edu (F.Q.); dshebitz@kean.edu (D.J.S.)

* Correspondence: kngoy@kean.edu

\begin{abstract}
This study analyzed the changes of land use and land cover (LULC) in New Jersey in the United States from 2007 to 2012. The goal was to identify the driving factors of these changes and to project the five-year trend to 2100. LULC data was obtained from the New Jersey Department of Environmental Protection. The original 86 classes were reclassified to 11 classes. Data analysis and projection were performed using TerrSet 2020. Results from 2007 to 2012 showed that the rate of LULC changes was relatively small. Most changes happened to brush/grasslands, mixed forest lands, farmlands and urban/developed lands. Urban/developed lands and the mixed-forest cover gained while farmlands lost. Using a multi-layer perceptron-Markov chain (MLP-MC) model, we projected the 2015 LULC and validated by actual data to produce a 2100 LULC. Changes from 2012 to 2100 showed that urban/developed lands, as well as brush/grasslands, would continue to gain, while farmlands would lose, although the projected landscape texture would likely be identical to the 2012 landscape. Human and natural factors were discussed. It was concluded that the MLP-MC model could be a useful model to predict short-term LULC change. Unexpected factors are likely to interfere in a long-term projection.
\end{abstract}

Keywords: New Jersey; land use and land cover changes; multi-layer perceptron-Markov chain model

\section{Introduction}

Land use and land cover are two closely related concepts. Land cover consists of natural or human-related physical features, such as vegetation, soil, water bodies and urbanization identifiable on the Earth's surface. Land use characterizes how humans utilize these features for the purpose of development and/or conservation. Due to the variability in the land cover types, the management or usage of one type of land cover can be handled differently from area to another within the same country or between different countries [1-3]. Despite these differences, many studies monitor and analyze land cover and land use together with a set of established classes [1].

Scientists have attempted to develop a universal classification scheme of land use and land cover (LULC) with no success due to the diversity and complexity of the LULC types worldwide. It has been a general practice to establish classification schemes and attach meanings to the classes at the national, regional or local scales [2,4]. The development of remote-sensing technologies, including satellite images and aerial photography, during the last four decades, as well as the progress made in geographic information systems (GIS), have sped up the inventory and the spatial analysis of LULC at various scales [1]. Analysis of LULC change using geospatial data and tools also provides essential information for assessing the impacts such a change would have on natural habitats and biodiversity, natural resources, climate and the ecosystem services.

Utilizing available remote sensing data, much research has been conducted to monitor LULC changes at different scales around the world and analyze the spatial patterns to 
study the controlling factors. These factors could be environmental, economic and/or political/administrative, and the results provide useful information to planners and decisionmakers. For instance, a global study analyzed the impacts of humans on LULC change [5]. Uvsh et al. [6] identified main factors contributing to forest-cover change in European Russia. Bracchetti et al. [7] analyzed LULC classes spanning five decades using aerial photographs to propose management plans in central Italy. In rural northeast Thailand, Crews-Meyer [8] proposed a method to assess the temporal persistence of LULC through pattern metrics.

Analyses of LULC using remote-sensing data have covered a wide range of areas. For example, using daytime and nighttime remote sensing, a study in China found that over 20 years, rapid urbanization and human migration have shown an overall improvement on the coastal eco-environment conditions [9]. A study in Mato Grosso, Brazil, applied multiple logistic regressions to the classified land cover from field observations and the Moderate Resolution Imaging Spectroradiometer (MODIS) datasets in addition to geophysical variables to find main factors likely to predict land cover conversion to farmlands [10]. In Western Ethiopia, remote-sensing data, in addition to household interviews and field observations, were used to identify and assess the contributing variables to geospatial and temporal LULC changes [11]. Classified remote-sensing data also helped identify areas with effective use of water for irrigation and areas of private land reclamation [12]. Vågen [13] used a time-series study of satellite imagery to analyze the rates of change between different land use types in Madagascar. The same method was used in Ethiopia, West Africa and Bhutan [14-17]. LULC changes were studied in United Arab Emirates to analyze their impacts on groundwater [18]. A recent bibliometric analysis of 1590 articles indexed in the Scopus database has documented worldwide research interests in LULC changes in the Amazon region [19].

In recent years, the application of machine-learning methods on LULC modeling has enhanced the modeling capabilities and allowed for predictions of future LULC changes [20,21]. Agent-based models, artificial neural networks (ANNs), cellular automata (CA) models, Markov chain (MC) models, regression models and other optimization models are among the widely used models. For instance, Markov chain models were applied in various places around world to predict LULC changes, including the Nakuru urban area in Kenya [22] and Bangladesh [23], among others.

Many studies have also used hybrid models to combine strengths of the individual methods. For example, cellular automata (CA)-Markov chain models take advantage of the spatial modeling capability of CA and temporal prediction capability of the Markov chain to predict future LULC changes. In the United States, it was used in a study to predict future distribution of land use in Minneapolis-St. Paul, Minnesota [24]. Similar approaches have also been applied in Malaysia [25], Nepal [26], India [27] and China [28], among others. Hybrid models included an alternative regression-based Markov (RBM) model to approximate transition probabilities of land cover types in the United States [29] and a multi-layer perceptron (MLP)-Markov chain model to simulate dynamic spatiotemporal LULC changes in China [30], in Stoney Creek Watershed, Canada [31] and in India [32]. Additional places where it was also applied include the Philippines [33], Brazil [34] and Turkey [35]. Ozturk [35] compared the CA-Markov chain with the MLP-Markov chain model and demonstrated that the later created better results using existing validation data.

As the interest of studying LULC with hybrid models such as the MLP-Markov model grows worldwide, it has been relatively less applied in local regions in the United States (US). We believe it is worth extending such study in the many states in the US to study the impact of LULC management where laws and regulations are very different from most other countries. For instance, any change to LULC in the US may be subjected to stricter environmental impact assessments, public hearings or even voting through ballot boxes that could hinder many human-led changes.

Our study extended such applications in a highly urbanized US state to analyze recent LULC change patterns and project into the future. The main difference between 
our study and the aforementioned studies is that it illustrated a case where strict land use regulations, regional land use planning and sound policies will likely result in balanced land development, protection of natural resources and minimal LULC changes. Additionally, the majority of previous studies that simulated future LULC changes were restricted to relatively smaller areas. Ours covered the entire state and benefitted statewide decision-making regarding land use management and planning. Specific objectives of this study included: (1) analyzing LULC changes during a five-year period from 2007 to 2012, (2) identifying driving factors of these changes, (3) projecting future LULC to 2100 and (4) evaluating the capability of the MLP-Markov chain model for long-term projections.

\section{Materials and Methods}

\subsection{Study Area}

The state of New Jersey is located on the east coast of the United States of America along the Atlantic Ocean (Figure 1). The land area covers a total of $19,230 \mathrm{~km}^{2}$ with an additional $3380 \mathrm{~km}^{2}$ extending into the Atlantic Ocean [36-38]. The mean elevation is $76 \mathrm{~m}$. The state can be divided into four physiographical regions. From north to south, these regions are the Appalachian Valley and Ridge, Highlands, Newark Basin Piedmont and Coastal Plain [38]. The Appalachian Valley and Ridge, located in the northwestern part, has an altitude of more than $488 \mathrm{~m}$ with the highest point at $549 \mathrm{~m}$. The Highlands region, which is mostly a plateau, has an elevation varying around $366 \mathrm{~m}$. To the south of the Highlands lies the Piedmont plain with an altitude of around $244 \mathrm{~m}$. The fourth and largest physiographic region is the Coastal Plain that occupies most of the southern part. It is divided in two parts (Inner Coastal Plain and Outer Coastal Plain), averaging $30 \mathrm{~m}$ of altitude [37-39].

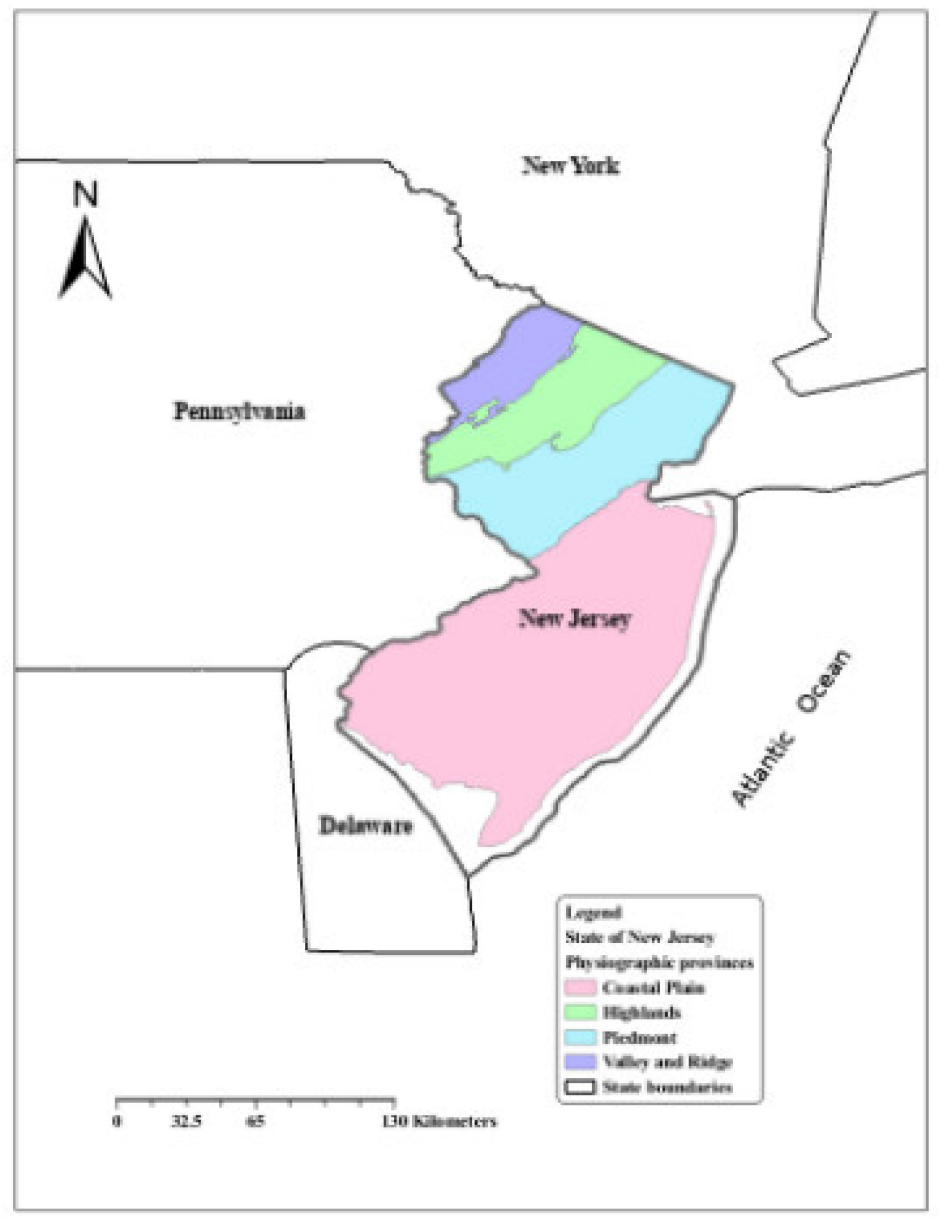

Figure 1. The state of New Jersey and its physiographic provinces. 
The state's natural ecosystem has been largely altered by anthropogenic activities over several hundred years. Nevertheless, a variety of forests cover about $40 \%$ of the state's land and most of them are secondary growth. Deciduous trees, including maple, birch and yellow poplar, grow in the north. In the southern plains, cedar, dwarf oak and pine prevail. The state has state-owned forest land and several other important public parks, including High Point State Park in the northwest corner and the Pine Barrens that occupies about 550,000 ha in the southeast [39]. On the Coastal Plain, there are salt marshes, swamps and meadows.

The New Jersey 2020 census results revealed that the population has increased to $9,288,994$ [40]. The state has one of the highest population densities in the US, with more than 460 persons per square kilometer [41,42]. Most of the population lives in urban areas in the northeast and southwest regions due to the proximity to New York City, NY, and Philadelphia, PA, the establishment of many major industries and the proximity to an important shipping corridor (U.S. Census Bureau, 2019 [43]). Despite its high urban population density, New Jersey has extensive rural areas characterized by large farms and relatively low population densities in counties, such as Sussex, Warren and Hunterdon in the northwest and Salem in the southwest [44,45].

\subsection{Data}

We downloaded LULC datasets from the New Jersey Department of Environmental Protection (NJDEP) through its Bureau of GIS data portal (https: / gisdata-njdep.opendata. arcgis.com/, accessed on 1 July 2021). Three years were of interest for this study, including 2007 (Figure 2), 2012 (Figure 3) and 2015 (Figure 4). These original LULC datasets were identified, delineated and digitized using the digital color infrared (CIR) orthophotos, with a ground resolution of about $30 \mathrm{~cm}$, as the primary source [46]. The entire state was classified into 86 LULC classes (Appendix A Table A1). The overall minimum classification accuracy for the three downloaded datasets was $85 \%$. The accuracy was greater than $90 \%$ for the developed land classes.

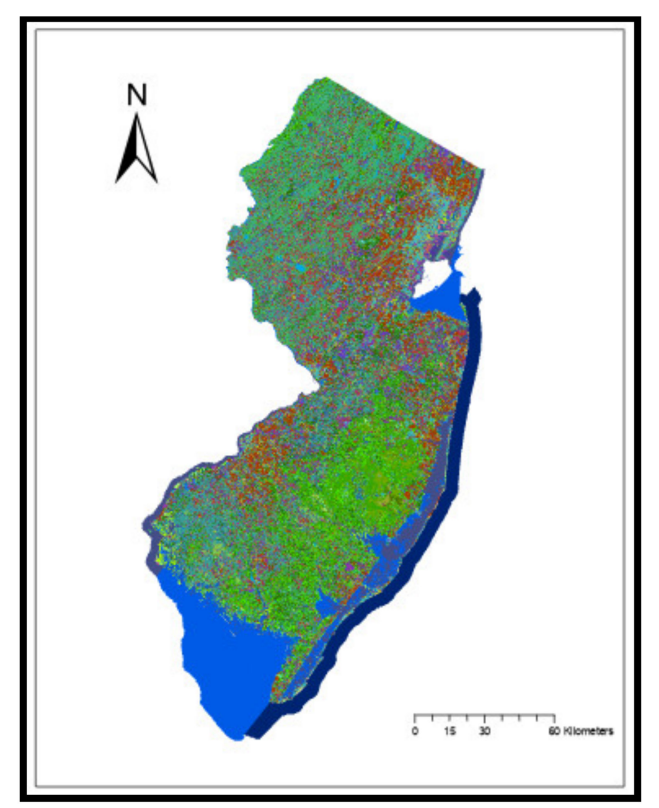

Figure 2. Original LULC of the state of New Jersey in 2007 (see Appendix A Table A1 for associated classes). 


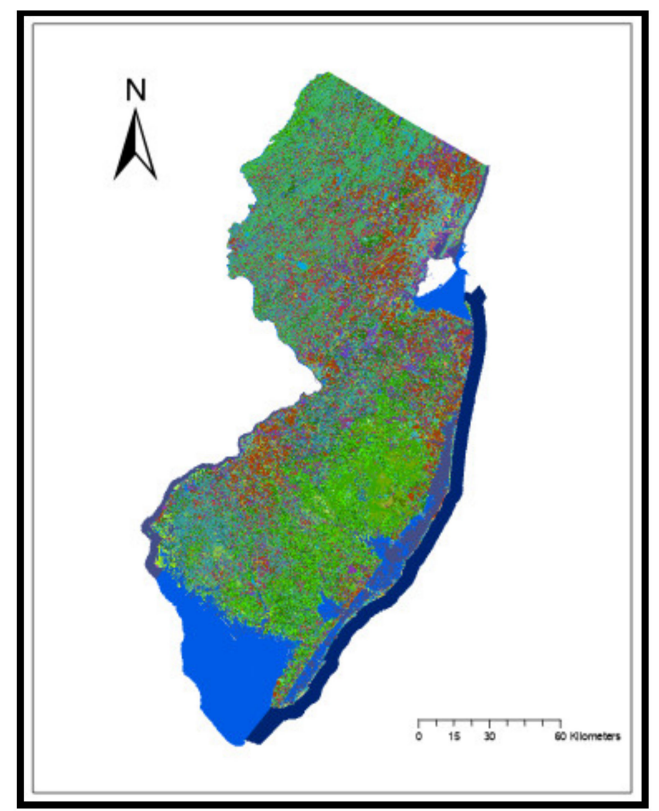

Figure 3. Original LULC of the state of New Jersey in 2012 (see Appendix A Table A1 for associated classes).

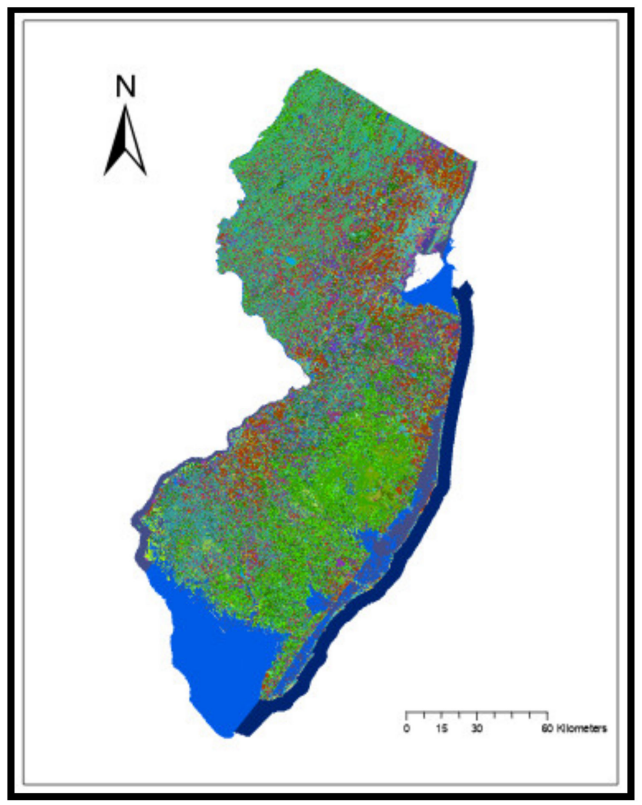

Figure 4. Original LULC of the state of New Jersey in 2015 (see Appendix A Table A1 for associated classes).

An initial examination of the downloaded data layers with ArcGIS Pro [47] revealed that the eastern boundaries of the state extended too far into the Atlantic Ocean. We clipped out the extra ocean water to include only the barrier islands along the east coast and a relatively small part of the bay in the south. Further, we grouped the 86 classes into 11 larger classes. The reclassification process consisted of grouping together closely related original classes and creating classes that align with the objectives of this study, which is to study land use change in the context of land development, farm and forest land changes. None of the original classes was excluded except the ocean water that was clipped out. We finally rasterized the data layers and exported to TerrSet 2020 [48] for further analysis (Figures 5-7). 


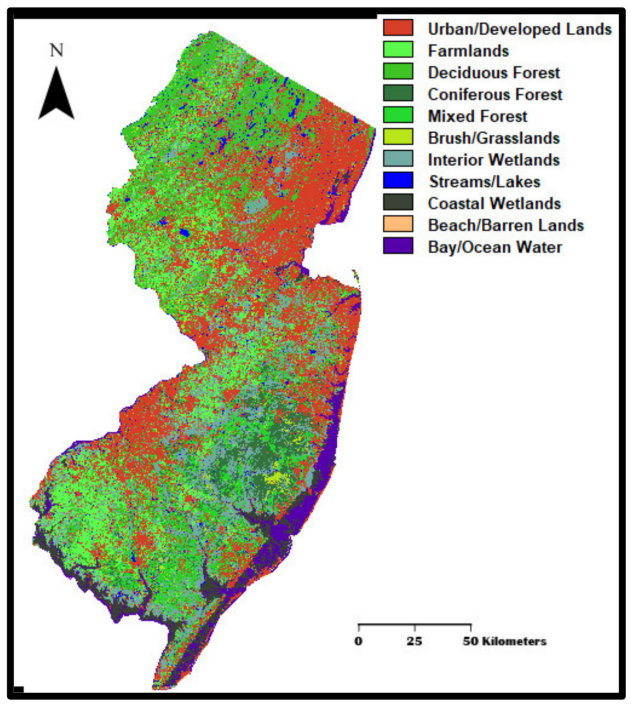

Figure 5. New Jersey LULC in 2007.

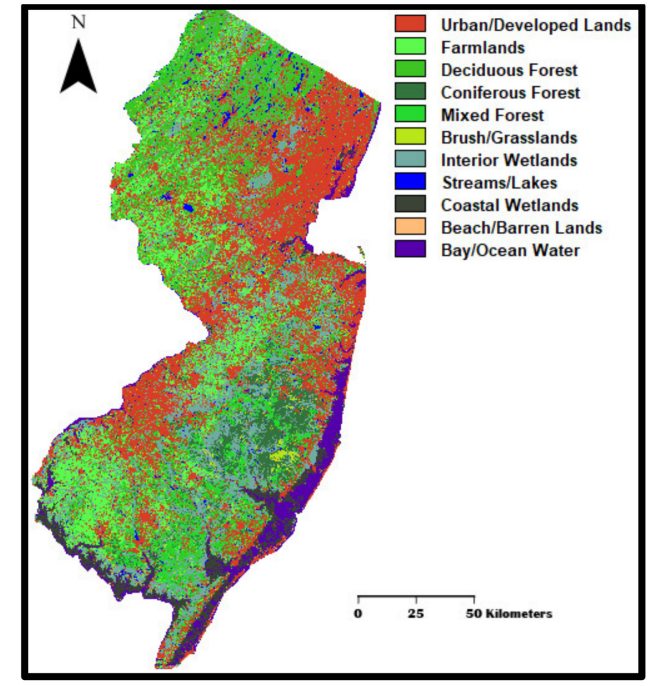

Figure 6. New Jersey LULC in 2012.

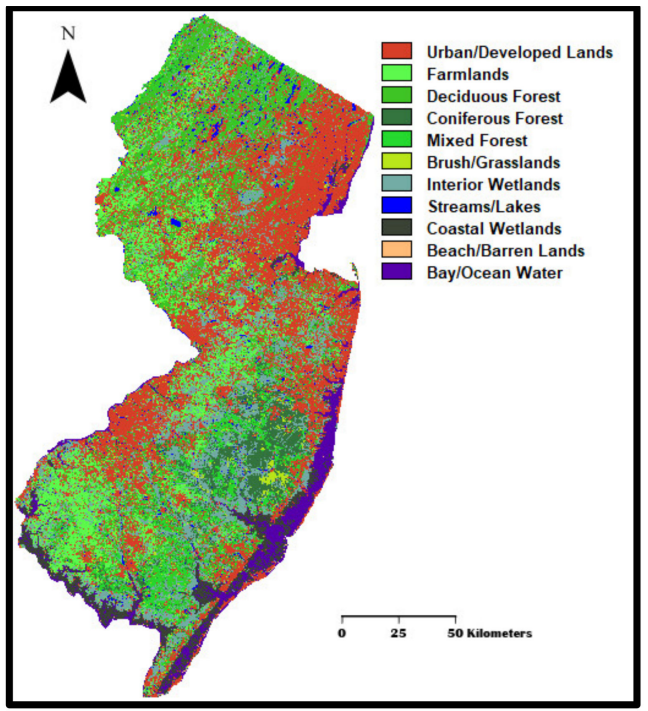

Figure 7. New Jersey LULC in 2015. 


\subsection{Method}

MLP-Markov chain modeling is integrated in the Land Change Modeler (LCM) module of the TerrSet software [48]. In LCM, tools for the assessment and prediction of land cover change and its implications are organized around four major task areas: (1) change analysis between an earlier and later land cover, (2) transition potentials (modeling the potential for land transitions), (3) change prediction (predicting the course of change into the future change prediction) and (4) planning interventions. We used this tool to analyze New Jersey's land cover changes from 2007 to 2012, derived transition potentials of land cover types trained with the 2007-2012 data, evaluated the derived potentials using the 2012-2015 data and projected further change to 2100.

\section{(1) Change Analysis}

We analyzed the LULC changes between 2007 and 2012 using the LCM task related to change analysis. First, we overviewed the gains and losses and derived the net change for each class. Next, we focused on the classes with detectable changes. For each of them, we identified the major contributors to these changes. We then used the third order polynomial equation option to analyze the spatial trend of changes. The classes that underwent the most changes were used to generate spatial trend maps. This step was mostly for visualization purposes, so not only the scientific community, but also the decision makers could eventually take appropriate actions to mitigate any potential trend that would likely negatively affect the wellbeing of the entire state's land system. We also created a map of areas that have remained unchanged between 2007 and 2012.

\section{(2) Transition potential modeling}

The changes identified were transitions from one land cover type to another. We used transition potential modeling in LCM to model the potential of a given land to transition or not to transition from one type to another. To explain the change that occurred from 2007 and 2012, we selected three explanatory variables: distance from disturbed areas, distance away from urban areas and a dummy variable of evidence likelihood transformation. Each variable is captured with a map of the same extent as the study area. The last map was created by determining the relative frequency with which different land cover type occurred within the state that transitioned from 2007 to 2012.

We used the MLP neural network to model the transition potential, which was recommended by the LCM developer as the most robust $[48,49]$. A MLP consists of multiple layers of nodes in a directed graph, with each layer fully connected to the next one (Figure 5). Except for nodes in the input layer, each node is a neuron (or processing element) with a nonlinear activation function [50]. Given data input $X_{i}(i=1,2, \ldots, N)$, the neural model output $y$ can be obtained with Equation (1) [49]:

$$
y=f\left(W^{T} X\right)=f\left(\sum_{i=0}^{N} W_{i} X_{i}+b\right)
$$

where $f$ is the activation function, $N$ is the number of the neurons, $W$ are the ANN model weights and $b$ is the bias vector.

A binary classification MLP's output is a value between 0 and 1, which could be considered as the probability of the positive target class. Model selection was performed by optimizing the number of hidden layers and the number of hidden neurons per layer of the MLP using training data (Figure 8) [48].

\section{(3) Change prediction}

Finally, based on the rates of change from 2007 and 2012 and the transition probabilities, we predicted the land cover in 2015 and 2100 using a MLP-Markov chain model $[25,27,50,51]$. We used the hard prediction model of the Markov chain based on the assumption that land allocation in New Jersey is a multi-objective decision process. 
The MLP-Markov chain formulas to predict land use change were based on the following equations (Equations (2) and (3)) [25,52]:

$$
\begin{gathered}
L_{(t+1)}=P_{i j} * L_{(t)} \\
P_{i j}=\left[\begin{array}{ccc}
P_{11} & P_{12} & P_{1 m} \\
P_{21} & P_{22} & P_{2 m} \\
\vdots & \vdots & \vdots \\
P_{m 1} & P_{m 2} & P_{m m}
\end{array}\right]
\end{gathered}
$$

where $L(t)$ and $L(t+1)$ represent land use status at time $t$ and $t+1$ respectively. $\left(0 \leq P_{i j}<1\right.$ and $\left.\sum_{j=1}^{m} P_{i j}=1,(i, j=1,3, \ldots m)\right)$ is the transition probability matrix.

(4) Model validation

We validated the model by comparing the predicted 2015 land cover to the 2015 classified land use map obtained from NJDEP. We used the built-in validation tool provided in TerrSet (Table 1) [48,52-55], as well as other metrics, such as a confusion matrix (Table 2 and Equations (4)-(6)) and the Kappa index (Equation (7)), through cross tabulation between the two land cover maps [56-59].

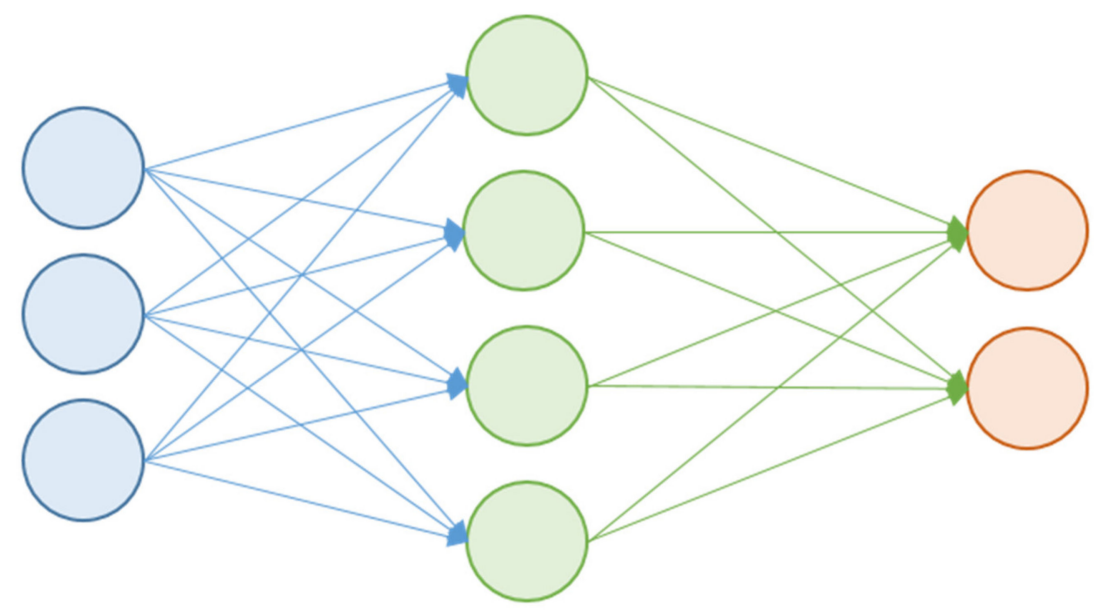

\section{Input Layer Hidden Layer Output Layer}

Figure 8. Schematic representation of a MLP with one hidden layer.

Table 1. Definitions of components of agreement and disagreement in terms of the seven critical points [48].

\begin{tabular}{cc}
\hline Name of Component & Definition \\
\hline Disagreement due to quantity & $\mathrm{P}(\mathrm{p})-\mathrm{P}(\mathrm{m})$ \\
\hline Disagreement at stratum level & $\mathrm{P}(\mathrm{m})-\mathrm{K}(\mathrm{m})$ \\
\hline Disagreement at grid cell level & $\mathrm{K}(\mathrm{m})-\mathrm{M}(\mathrm{m})$ \\
\hline Agreement at grid cell level & $\mathrm{MAX}[\mathrm{M}(\mathrm{m})-\mathrm{H}(\mathrm{m}), 0]$ \\
\hline Agreement at stratum level & $\mathrm{MAX}[\mathrm{H}(\mathrm{m})-\mathrm{N}(\mathrm{m}), 0]$ \\
\hline Agreement due to quantity & then $\mathrm{MIN}[\mathrm{N}(\mathrm{m})-\mathrm{N}(\mathrm{n}), \mathrm{H}(\mathrm{m})-\mathrm{N}(\mathrm{n}), \mathrm{M}(\mathrm{m})-\mathrm{N}(\mathrm{n})]$, \\
& $\mathrm{else} 0$ \\
\hline Agreement due to chance & $\mathrm{MIN}[\mathrm{N}(\mathrm{n}), \mathrm{N}(\mathrm{m}), \mathrm{H}(\mathrm{m}), \mathrm{M}(\mathrm{m})]$ \\
\hline
\end{tabular}


Table 2. Confusion matrix.

\begin{tabular}{ccccccc}
\hline & \multicolumn{5}{c}{ Predicted Image } \\
\hline \multirow{3}{*}{ Classified image } & & $\mathrm{A}$ & $\mathrm{B}$ & $\mathrm{C}$ & Total \\
\cline { 2 - 6 } & $\mathrm{a}$ & $\mathrm{aA}$ & $\mathrm{aB}$ & $\mathrm{aC}$ & $\sum \mathrm{a}$ \\
\cline { 2 - 6 } & $\mathrm{b}$ & $\mathrm{bA}$ & $\mathrm{bB}$ & $\mathrm{bC}$ & $\sum \mathrm{b}$ \\
\cline { 2 - 6 } & $\mathrm{c}$ & $\mathrm{cA}$ & $\mathrm{cB}$ & $\mathrm{cC}$ & $\sum \mathrm{c}$ \\
\hline & Total & $\sum \mathrm{A}$ & $\sum \mathrm{B}$ & $\sum \mathrm{C}$ & $\mathrm{N}$ = grand total \\
\hline
\end{tabular}

The seven mathematical expressions, $\mathrm{N}(\mathrm{n}), \mathrm{N}(\mathrm{m}), \mathrm{H}(\mathrm{m}), \mathrm{M}(\mathrm{m}), \mathrm{K}(\mathrm{m}), \mathrm{P}(\mathrm{m})$ and $\mathrm{P}(\mathrm{p})$, represent the measures of agreement between two maps (2015 LULC classified map and 2015 LULC predicted map). Usually $0 \leq \mathrm{N}(\mathrm{n}) \leq \mathrm{N}(\mathrm{m}) \leq \mathrm{H}(\mathrm{m}) \leq \mathrm{M}(\mathrm{m}) \leq \mathrm{K}(\mathrm{m}) \leq \mathrm{P}(\mathrm{m}) \leq \mathrm{P}(\mathrm{p})=1$. This sequence partitions the interval $(0,1)$ into components of the agreement and disagreement between the reference map and the comparison map. $\mathrm{M}(\mathrm{m})$ is the total proportion correct; thus, $1-\mathrm{M}(\mathrm{m})$ is the total proportion of disagreement between the reference map and the comparison map [48].

Table 1 defines the component of agreement due to chance as the minimum of $N(n)$, $\mathrm{N}(\mathrm{m}), \mathrm{H}(\mathrm{m})$ and $\mathrm{M}(\mathrm{m})$. The component of agreement due to quantity is $\mathrm{N}(\mathrm{m})-\mathrm{N}(\mathrm{n})$. The component of agreement at the stratum level is $\mathrm{H}(\mathrm{m})-\mathrm{N}(\mathrm{m})$. The component of agreement at the grid cell level is $\mathrm{M}(\mathrm{m})-\mathrm{H}(\mathrm{m})$. Additionally, this table provides the components of disagreement if $\mathrm{M}(\mathrm{m}) \leq \mathrm{K}(\mathrm{m}) \leq \mathrm{P}(\mathrm{m}) \leq \mathrm{P}(\mathrm{p})$ [48].

Overall accuracy (OvAc):

$$
\mathrm{OvAc}=(\mathrm{aA}+\mathrm{bB}+\mathrm{cC}) / \mathrm{N}
$$

Producer's accuracy (PrAc): Example for class A in Table 1:

$$
\operatorname{PrAc}=\mathrm{aA} / \sum \mathrm{A}
$$

User's accuracy (UsAc): Example for class A in Table 1, it equals:

$$
\mathrm{UsAc}=\mathrm{aA} / \sum \mathrm{a}
$$

The Kappa index of agreement is calculated using Equation (7).

$$
k=\frac{P(A)-P(E)}{1-P(E)}
$$

where $P(A)$ is the number of times the $k$ raters agree and $P(E)$ is the number of times the $k$ raters are expected to agree only by chance [12].

(5) Land cover analysis

We analyzed the predicted 2100 LULC using four landscape metrics, including fragmentation index, relative richness, diversity and dominance.

Fragmentation index is computed using the following Equation (8) [60]:

$$
\mathrm{F}=(\mathrm{M}-1) /(\mathrm{N}-1)
$$

where $\mathrm{M}$ is the number of map regions and $\mathrm{N}$ is the number of places. This index ranges from 0.0 , for a pattern in which all areal units have been assigned to a single class, to 1.0, when no two contiguous places have been allocated to the same mapping category.

Formulas for calculating dominance (Equation (9)), relative richness (Equation (10)) and diversity (Equation (11)) are based on Turner [61].

Dominance $\left(D_{o}\right)$

$$
D_{o}=H_{\max }+\sum_{k=1}^{s}\left(P_{k}\right) \ln \left(P_{k}\right)
$$


where $s=$ number of habitats observed, $P_{k}=$ the proportion of the landscape in habitat $k$ and $H_{\max }=\ln (s)$ is the maximum diversity when habitats occur in equal proportions.

Relative richness $(R)$

$$
R=\frac{s}{s_{\max }}+100
$$

where $s=$ the number of different habitat types present and $s_{\max }=$ the maximum number of habitat types possible.

Diversity $(H)$

$$
H=-\sum_{k=1}^{s}\left(P_{k}\right) \ln \left(P_{k}\right)
$$

where $s=$ number of habitats observed and $P_{k}=$ the proportion of the landscape in habitat $k$.

\section{Results}

\subsection{Land Cover Change between 2007 and 2012}

From 2007 to 2012, the total LULC types expanded by 12.16 ha and about the same area was lost in the state of New Jersey (Figure 9). The most changes happened to brush/grasslands, mixed forest lands, farmlands and urban/developed lands. Among these, urban/developed lands had a net gain of 1.80 ha and the mixed-forest cover had a net gain of 0.45 ha, while farmlands had a net loss of 1.50 ha (Figure 10).

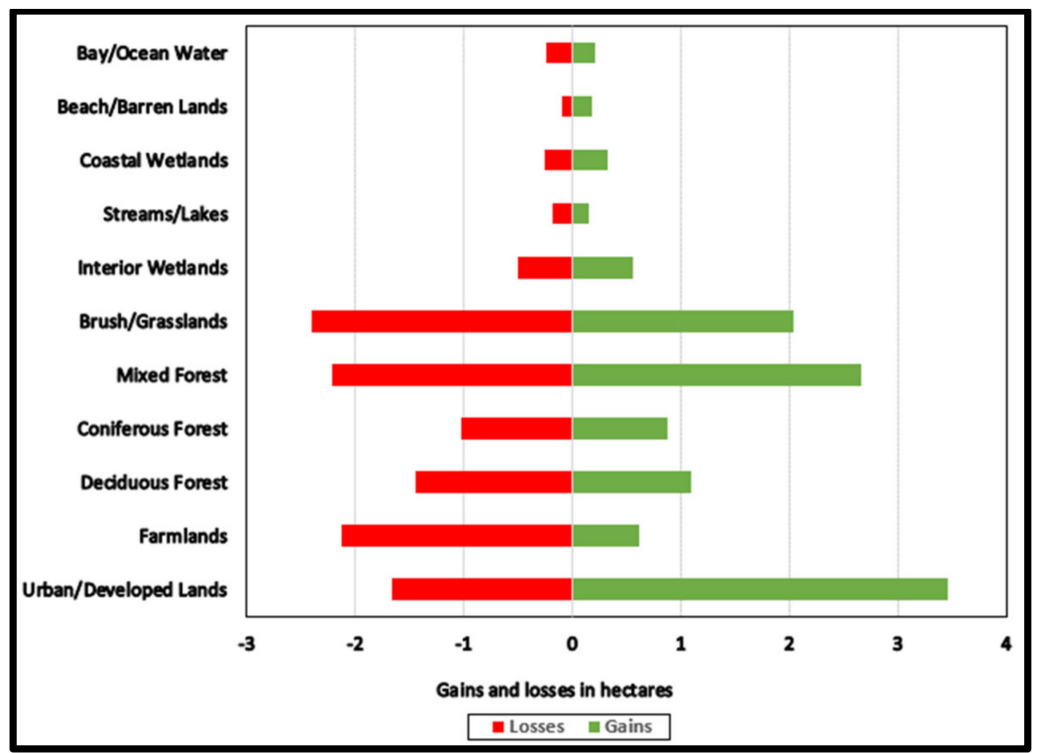

Figure 9. Gains and losses by each class in New Jersey from 2007 to 2012.

Six land cover types contributed to the net gain experienced by urban/developed lands including farmlands, forest, brush/grasslands and interior wetlands (Figure 11). The most contributions were from farmlands (about $0.8 \mathrm{ha}$ ) and deciduous forests ( $0.72 \mathrm{ha})$. A very small portion of land (about $0.1 \mathrm{ha}$ ) was lost by urban/developed lands to coastal wetlands.

Contributions to the net gain by mixed-forest cover was from three classes (Figure 12). Farmlands contributed with 0.55 ha, deciduous forests with 0.42 ha and coniferous forests with 0.21 ha. There was about 0.57 ha of mixed-forest cover converted to brush/grasslands. A small area was lost to urban/developed lands.

Three maps were generated from our analyses showing the generalized trends of classes with the most changes from 2007 to 2012. The likelihood of changing from farmlands to urban/developed lands (Figure 13a) is higher in the western part of the state from around the Camden and Trenton areas, even though the largest urbanized areas are located in the northeast near New York City in New York. The state's western part is also where more farmlands are located and more likely to contribute to mixed forests (Figure 13b) with areas around Camden showing the most likelihood. The Highlands region in the northwest of 
the state is mostly covered by forest. It is where the chance for deciduous forest to change to mixed forest is the highest (Figure 13c). We have also created a map of areas that have not changed from 2007 to 2012 (Figure 14). The majority of the state's land has remained unchanged in terms of land use and land cover during this five-year period. Those that have experienced change are some relatively smaller areas scattered all over the state and difficult to visualize.

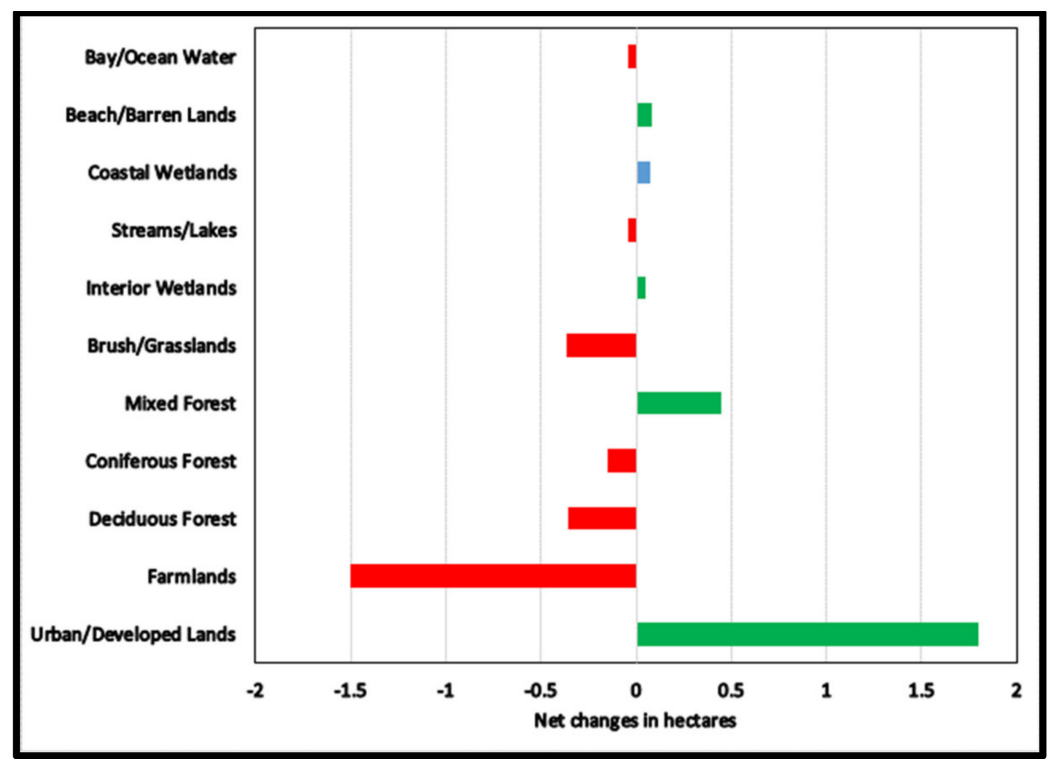

Figure 10. Net change within each class in New Jersey from 2007 to 2012 . The net change for each class was calculated by subtracting the gains from losses based on results from Figure 9. If the gains were higher than the losses, results were positive (green color) otherwise, results were negative (red color).

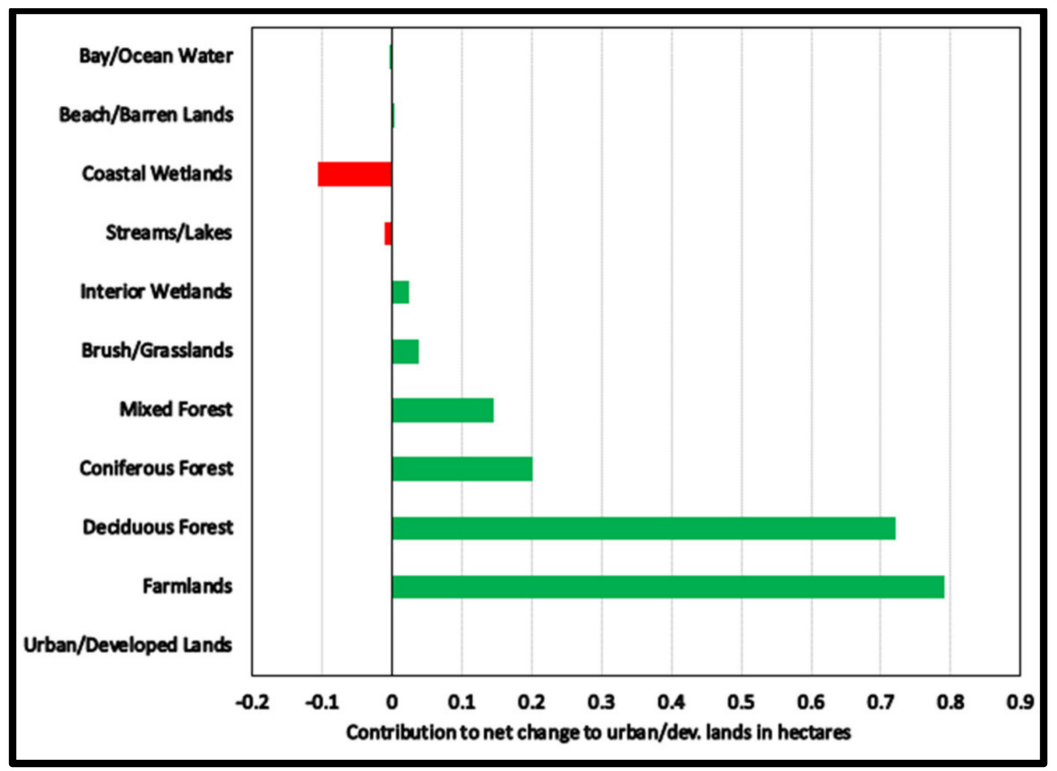

Figure 11. Contribution to net change experienced by urban/developed lands. 


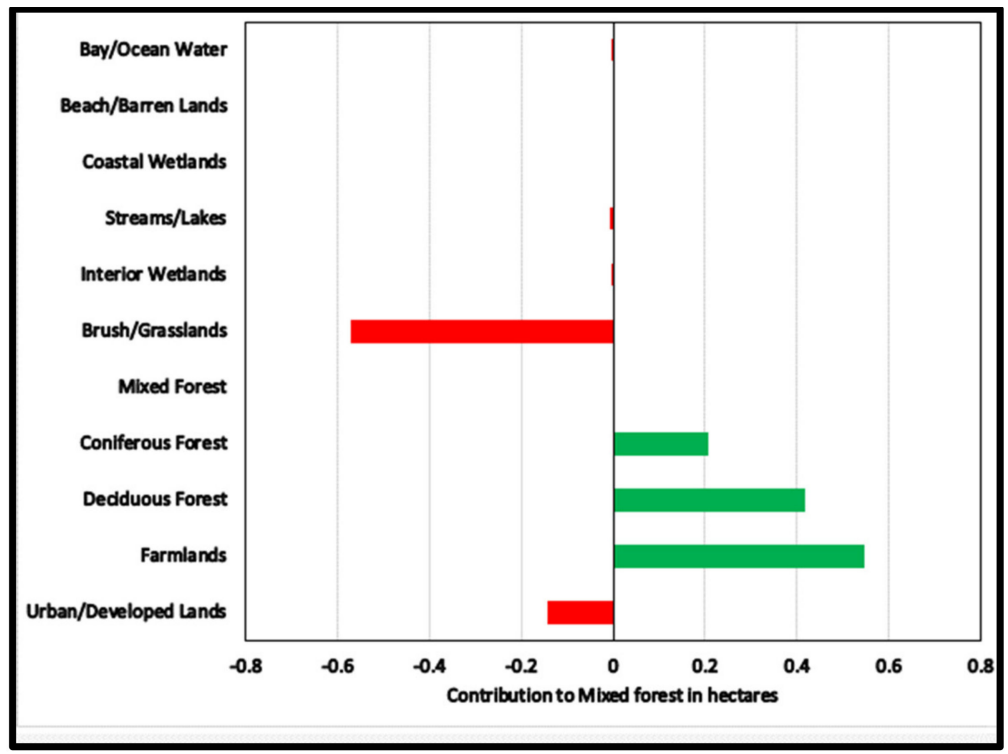

Figure 12. Contribution to net change experienced by mixed-forest land cover.

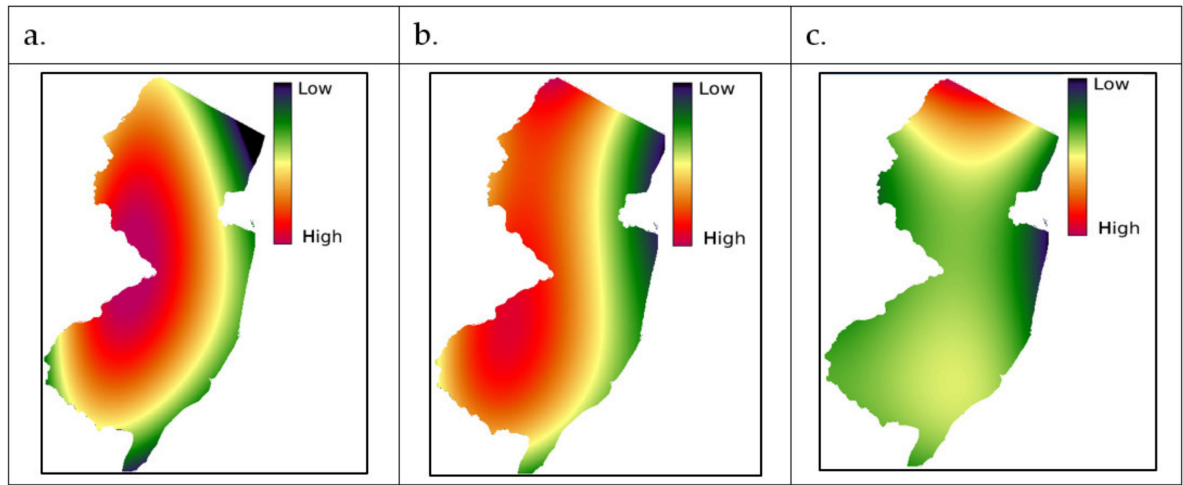

Figure 13. Maps of spatial trend of changes (a) from urban/developed areas into farmlands, (b) from farmlands to mixed-forest cover (c) from deciduous-forest cover to mixed-forest cover.

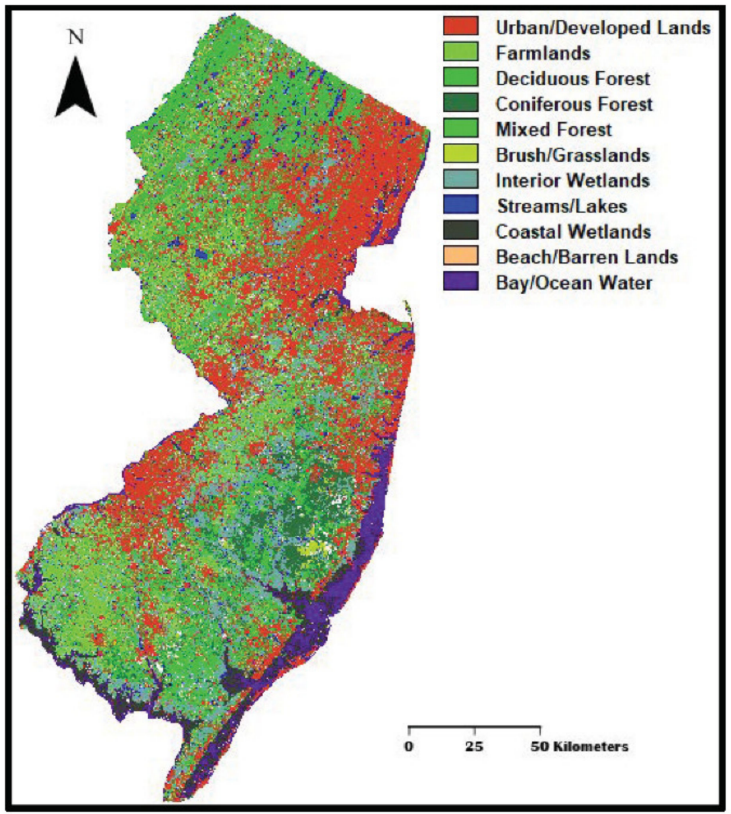

Figure 14. Map of areas that did not change between 2007 and 2012. 


\subsection{Transition Model}

Using the three explanatory variables and the LULC maps of 2007 and 2012, we trained a MLP neural network model using the transition sub-model within LCM. Table 3 shows sensitivity analysis results of the model. It shows that we achieved an accuracy rate of $83 \%$ with all variables. A skill value of 0.78 (Table $3 a-c)$ is above the advised numbers suggested by the software developer (see tutorial [48,62]). The skill measure is the difference between the measured accuracy and the accuracy expected by chance. The accuracy and the skill values denote that the first variable, distance to disturbed areas, is the most influential in the model performance. The accuracy and skill measures were even higher, 92.4 and 0.90 respectively, when holding constant the variable "distance from urban/developed lands". However, if the model skill of holding a variable constant was similar with the skill of modeling with all variables, the variable does not affect the model significantly and it can be removed [31]. This was not the case in our model results. Table $3 \mathrm{c}$ shows LULC more likely to transition or not to another LULC type. Mixed forest has the highest likelihood to transition to brush/grasslands, and farmlands are also likely to transition to urban/developed lands. Based on results from Table 3, Table 4 was automatically generated to be used in the creation of the predicted LULC map. This table lists the resulting probabilities matrix indicating the probability that each LULC type will change to another type. It shows that the probability for each LULC type is very high [48].

Table 3. Transition sub-model results: Sensitivity of the model to forcing independent variables to be constant: (a) Forcing a single independent variable to be constant. (b) Backwards stepwise constant forcing. (c) Model skill breakdown by transition and persistence.

\begin{tabular}{cccc}
\hline (a) & & & \\
\hline Model & Accuracy (\%) & Skill Measure & Influence Order \\
\hline With all variables & 83.32 & 0.7776 & N/A \\
\hline Var. 1 constant & 35.25 & 0.1367 & 1 (most influential) \\
\hline Var. 2 constant & 92.4 & 0.8986 & 3 (least influential) \\
\hline Var. 3 constant & 56.24 & 0.4165 & 2 \\
\hline (b) & & & \\
\hline Model & Accuracy (\%) & Skill Measure & \\
\hline With all variables & 83.32 & 0.7776 & \\
\hline Step 1: var. [2] constant & 92.4 & 0.8986 & \\
\hline Step 2: var. [2,3] constant & 50 & 0.3334 & \\
\hline (c) & & & \\
\hline Class & & & \\
\hline Skill Measure & \\
\hline Transition: Farmlands to & & \\
\hline Transition: Mixed Forest to \\
Brush/Grasslands
\end{tabular}

\subsection{Predictions of Land Use Change in 2015 and Model Validation}

Using the derived transition model, we proceeded to predict a 2015 LULC map (Figure 15). This step served a validation step as we had an existing classified 2015 LULC with a general accuracy of $85 \%$ and more than $90 \%$ in urban areas. We conducted three validation procedures to assess the level of accuracy to see whether they all corroborated our findings. 
Table 4. Transition probabilities grid.

\begin{tabular}{|c|c|c|c|c|c|c|c|c|c|c|c|c|}
\hline & & \multicolumn{11}{|c|}{ Probability of Changing to These Classes } \\
\hline & & $\begin{array}{l}\text { Urban/ } \\
\text { Developed } \\
\text { Lands }\end{array}$ & Farmlands & $\begin{array}{l}\text { Deciduous } \\
\text { Forest }\end{array}$ & $\begin{array}{l}\text { Coniferous } \\
\text { Forest }\end{array}$ & $\begin{array}{l}\text { Mixed } \\
\text { Forest }\end{array}$ & $\begin{array}{c}\text { Brush/ } \\
\text { Grasslands }\end{array}$ & $\begin{array}{c}\text { Interior } \\
\text { Wetlands }\end{array}$ & $\begin{array}{l}\text { Streams/ } \\
\text { Lakes }\end{array}$ & $\begin{array}{c}\text { Coastal } \\
\text { Wetlands }\end{array}$ & $\begin{array}{l}\text { Beach/ } \\
\text { Barren } \\
\text { Lands }\end{array}$ & $\begin{array}{l}\text { Bayl } \\
\text { Ocean } \\
\text { Water }\end{array}$ \\
\hline \multirow{11}{*}{ 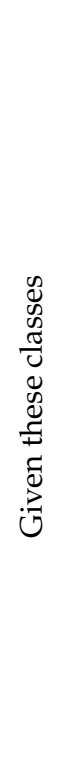 } & $\begin{array}{c}\text { Urban/ } \\
\text { Developed Lands }\end{array}$ & 0.9942 & 0.0008 & 0.0002 & 0 & 0.0015 & 0.0011 & 0.0014 & 0.0003 & 0.0005 & 0 & 0 \\
\hline & Farmlands & 0.0102 & 0.979 & 0 & 0 & 0.0074 & 0.0033 & 0 & 0.0001 & 0 & 0 & 0 \\
\hline & Deciduous Forest & 0.0055 & 0.0004 & 0.9896 & 0 & 0.0041 & 0.0003 & 0.0001 & 0 & 0 & 0 & 0 \\
\hline & Coniferous Forest & 0.0038 & 0.0002 & 0.0002 & 0.9805 & 0.009 & 0.0061 & 0 & 0.0001 & 0 & 0 & 0 \\
\hline & $\begin{array}{l}\text { Mixed } \\
\text { Forest }\end{array}$ & 0.0091 & 0.0031 & 0.0021 & 0.0042 & 0.9638 & 0.0174 & 0.0001 & 0.0001 & 0 & 0 & 0 \\
\hline & $\begin{array}{c}\text { Brush/ } \\
\text { Grasslands }\end{array}$ & 0.0158 & 0.0049 & 0.0403 & 0.028 & 0.0216 & 0.889 & 0.0001 & 0.0002 & 0.0001 & 0 & 0 \\
\hline & Interior Wetlands & 0.0031 & 0.0001 & 0 & 0 & 0 & 0 & 0.9964 & 0.0003 & 0 & 0 & 0 \\
\hline & $\begin{array}{l}\text { Streams/ } \\
\text { Lakes }\end{array}$ & 0.0034 & 0.0001 & 0 & 0 & 0.0002 & 0 & 0.0066 & 0.9894 & 0.0001 & 0 & 0.0001 \\
\hline & Coastal Wetlands & 0.0011 & 0 & 0 & 0 & 0 & 0 & 0.0001 & 0 & 0.9929 & 0.0014 & 0.0044 \\
\hline & $\begin{array}{c}\text { Beach/ } \\
\text { Barren Lands }\end{array}$ & 0.0063 & 0 & 0 & 0.0006 & 0.0045 & 0.008 & 0.0002 & 0 & 0.0728 & 0.854 & 0.0537 \\
\hline & Bay/Ocean Water & 0.0001 & 0 & 0 & 0 & 0 & 0 & 0 & 0 & 0.0029 & 0.003 & 0.994 \\
\hline
\end{tabular}




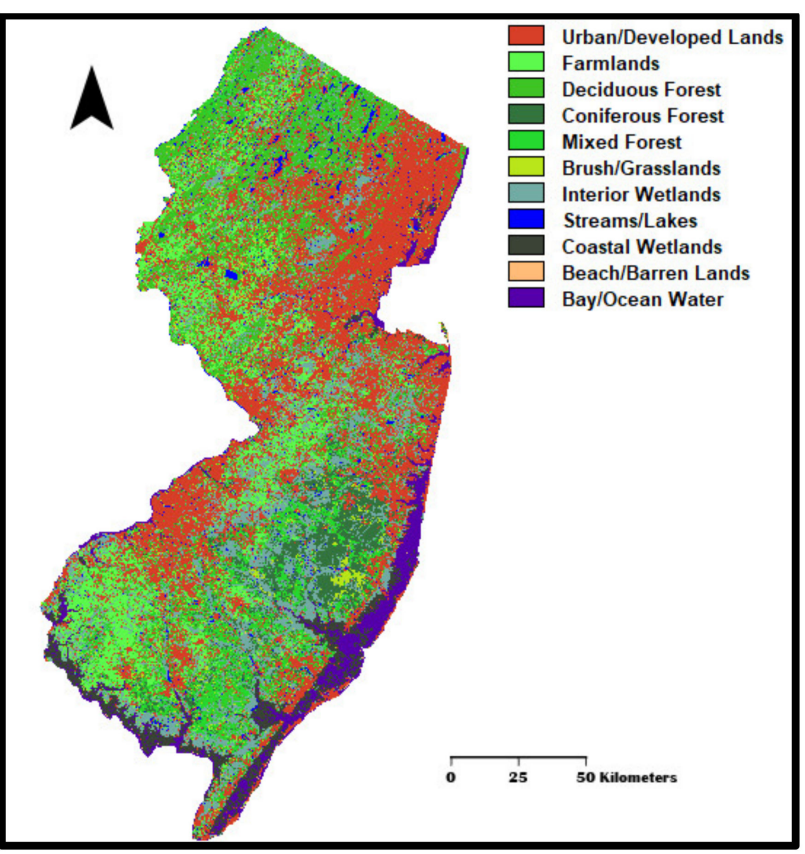

Figure 15. New Jersey land cover predicted in 2015.

The first procedure used the MLP validation for classification agreements/disagreements (Table 5). In Table 1, we stated that for the two maps to agree the following conditions must be met: $0 \leq \mathrm{N}(\mathrm{n})<\mathrm{N}(\mathrm{m}) \leq \mathrm{H}(\mathrm{m}) \leq \mathrm{M}(\mathrm{m}) \leq \mathrm{K}(\mathrm{m}) \leq \mathrm{P}(\mathrm{m}) \leq \mathrm{P}(\mathrm{p})=1$. Results from Table 5 are correctly displaying these sequences $(0 \leq 0.0833 \leq 0.2720 \leq 0.2720 \leq 0.9506 \leq 0.9982$ $\leq 0.9982 \leq 1.0000=1$ ). Therefore, there was agreement between the 2015 classified map and the 2015 predicted map.

Table 5. MLP validation results: Classification agreement/disagreement according to ability to specify accurately quantity and allocation.

\begin{tabular}{cccc}
\hline & \multicolumn{3}{c}{ Information of Quantity } \\
\hline Information of Allocation & No(n) & Medium $(\mathbf{m})$ & Perfect(p) \\
\hline Perfect $[\mathrm{P}(\mathrm{x})]$ & $\mathrm{P}(\mathrm{n})=0.5235$ & $\mathrm{P}(\mathrm{m})=0.9982$ & $\mathrm{P}(\mathrm{p})=1.0000$ \\
PerfectStratum[K(x)] & $\mathrm{K}(\mathrm{n})=0.5235$ & $\mathrm{~K}(\mathrm{~m})=0.9982$ & $\mathrm{~K}(\mathrm{p})=1.0000$ \\
MediumGrid[M(x)] & $\mathrm{M}(\mathrm{n})=0.4909$ & $\mathrm{M}(\mathrm{m})=0.9506$ & $\mathrm{M}(\mathrm{p})=0.9492$ \\
MediumStratum[H(x)] & $\mathrm{H}(\mathrm{n})=0.0833$ & $\mathrm{H}(\mathrm{m})=0.2720$ & $\mathrm{H}(\mathrm{p})=0.2722$ \\
No[N(x)] & $\mathrm{N}(\mathrm{n})=0.0833$ & $\mathrm{~N}(\mathrm{~m})=0.2720$ & $\mathrm{~N}(\mathrm{p})=0.2722$ \\
\hline AgreementChance & 0.0833 & & \\
AgreementQuantity & 0.1887 & & \\
AgreementStrata & 0.0000 & & \\
AgreementGridcell & 0.6785 & & \\
DisagreeGridcell & 0.0476 & & \\
DisagreeStrata & 0.0000 & & \\
DisagreeQuantity & 0.0018 & & \\
Kno & 0.9461 & & \\
Klocation & 0.9344 & & \\
KlocationStrata & 0.9344 & & \\
Kstandard & 0.9321 & & \\
\hline
\end{tabular}

It was stated in Table 1 that $\mathrm{M}(\mathrm{m})$ is the total proportion of correct agreement between the two maps. Our Table 5 results show that $\mathrm{M}(\mathrm{m})$ is 0.9506 , which displays a high degree of correctness between the 2015 classified map and the 2015 predicted map. This overall agreement can be broken down in four components: (1) The agreement due to 
chance, $\mathrm{N}(\mathrm{n})$, is 0.0833 . It is the agreement one would get with no information of location and no information of quantity. (2) The agreement due to quantity, $N(m)-N(n)$, is 0.1887 . This agreement means that the maps being compared are somewhat accurate in terms of their specification of quantity of each category. (3) The agreement due to stratification, $\mathrm{H}(\mathrm{m})-\mathrm{N}(\mathrm{m})$, is 0.0000 . This additional agreement attests that the two maps are somewhat accurate in terms of their specification of quantity of each category within each stratum. (4) The agreement due to grid cell level location, $\mathrm{M}(\mathrm{m})-\mathrm{H}(\mathrm{m})$, is 0.6785 . This last agreement indicates that the two maps are somewhat accurate in terms of their specification of the grid cell level location of each category within each stratum.

Table 5 also shows the level of disagreement between the two maps. The total proportion of disagreement $(1-\mathrm{M}(\mathrm{m}))$ is 0.05 . A detail analysis of the disagreement shows that the disagreement at the grid cell level, $\mathrm{K}(\mathrm{m})-\mathrm{M}(\mathrm{m})$, is 0.0476 . This is the amount of disagreement associated with the fact that the two maps being compared failed to specify perfectly the correct locations of categories at the grid cell level within strata. This disagreement is very small. The second type of disagreement is at the stratum level, $\mathrm{P}(\mathrm{m})-\mathrm{K}(\mathrm{m})$. It is 0.0000 and corresponds to the amount of disagreement associated with the fact that the comparison failed to specify perfectly the correct quantity of each category within each stratum. This result shows that there is no disagreement between the 2015 predicted and 2015 classified maps. The last disagreement is due to quantity, $\mathrm{P}(\mathrm{p})-\mathrm{P}(\mathrm{m})$. Results from Table 5 show that it is 0.0018 , corresponding to the disagreement associated with the fact that the comparison process failed to specify perfectly the correct quantity of each category according to the reference map. In this specific case, there is almost no disagreement between the two maps.

Table 5 also lists overall Kappa indices derived from running a MLP validation algorithm. It includes standard Kappa ( $\left.\mathrm{K}_{\text {standard }}\right)$ of 0.9321, Kappa for no information $\left(\mathrm{K}_{\mathrm{no}}\right)$ of 0.9461 , Kappa that indicates how well the grid cells are located on the landscape $\left(\mathrm{K}_{\text {location }}\right)$ of 0.9344 and Kappa for stratum-level location $\left(\mathrm{K}_{\text {locationstrata }}\right)$ of 0.9344 . These values are indicative of a high validation accuracy between the predicted 2015 LULC map and the already 2015 LULC classified map.

The other two validation methods showed a similar high degree of accuracy between the two maps. The overall accuracy measured using the confusion matrix is 0.91 (or 91\%) (Table 6). The producer's accuracy for each class was also high for most classes, with brush/grasslands and stream/lakes being relatively lower. User's accuracy showed the same pattern. The Kappa Index of Agreement (KIA) [33] (Table 7) was also high with an overall index of 0.93 (or 93\%). The degree of accuracy of KIA was almost the same as the one we produced when we validated using the MLP validation process. The difference was that this one also evaluated the accuracy for each. The detailed accuracy distribution by classes showed the same variation with the confusion matrix. Overall, we achieved a considerably high accuracy with the model. We then used the model to make a 2100 projection (Figure 16).

\subsection{Prediction of Land Use Change in 2100}

Figure 16 shows the predicted land cover of New Jersey in the year 2100. Similar to the analysis of LULC change we did for 2007-2012, we analyzed the changes for 2012-2100 using the predicted 2100 LULC map (Figures 17 and 18). The results suggest that urban/developed lands will gain 14.14 ha and brush/grasslands 3.24 ha, while farmlands will lose 14.14 ha and mixed-forest cover 3.24 ha. All the gains that urban/developed lands will likely experience will come from farmlands, and gains to brush/grasslands will likely originate from mixed-forest cover. 
Table 6. Confusion matrix.

\begin{tabular}{|c|c|c|c|c|c|c|c|c|c|c|c|c|c|c|}
\hline \multicolumn{15}{|c|}{ Predicted Land Cover in 2015} \\
\hline \multirow{12}{*}{ 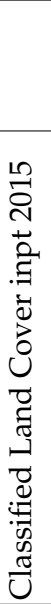 } & Category & $\begin{array}{l}\text { Urban/ } \\
\text { Developed } \\
\text { Lands }\end{array}$ & Farmlands & $\begin{array}{c}\text { Deci } \\
\text { Duous } \\
\text { Forest }\end{array}$ & $\begin{array}{c}\text { Coni } \\
\text { Ferous } \\
\text { Forest }\end{array}$ & $\begin{array}{l}\text { Mixed } \\
\text { Forest }\end{array}$ & $\begin{array}{c}\text { Brush/ } \\
\text { Grasslands }\end{array}$ & $\begin{array}{c}\text { Interior } \\
\text { Wetlands }\end{array}$ & $\begin{array}{l}\text { Streams } \\
\text { Lakes }\end{array}$ & $\begin{array}{c}\text { Coastal } \\
\text { Wetlands }\end{array}$ & $\begin{array}{l}\text { Beach/ } \\
\text { Barren } \\
\text { Lands }\end{array}$ & $\begin{array}{l}\text { Bay/ } \\
\text { Ocean } \\
\text { Water }\end{array}$ & Total & $\begin{array}{c}\text { User's } \\
\text { Accuracy }\end{array}$ \\
\hline & $\begin{array}{l}\text { Urban/ } \\
\text { Developed Lands }\end{array}$ & $1,625,588$ & 18,535 & 65,138 & $\begin{array}{l}3359 \\
9751\end{array}$ & 11,040 & 25,682 & 6173 & 867 & 124 & 1135 & $1,767,392$ & 0.919767 & \\
\hline & Farmlands & 20,867 & 538,568 & 14,156 & 665 & 3778 & 4074 & 9626 & 875 & 4 & 1 & 5 & 592,619 & 0.908793 \\
\hline & Deciduous Forest & 60,701 & 13,337 & 705,797 & 3699 & 12,423 & 6740 & 28,548 & 4635 & 110 & 125 & 103 & 836,218 & 0.844035 \\
\hline & Coniferous Forest & 1707 & 535 & 2273 & 305,392 & 1868 & 983 & 1165 & 227 & 27 & 15 & 2 & 314,194 & 0.971985 \\
\hline & Mixed Forest & 7352 & 3252 & 11,366 & 3017 & 334,737 & 8947 & 4385 & 807 & 33 & 16 & 53 & 373,965 & 0.895102 \\
\hline & Brush/Grasslands & 9791 & 3756 & 6793 & 1111 & 3465 & 100,880 & 3512 & 547 & 80 & 22 & 115 & 130,072 & 0.77557 \\
\hline & Interior Wetlands & 24,064 & 10,242 & 27,188 & 1190 & 4141 & 3868 & 776,431 & 7171 & 323 & 14 & 186 & 854,818 & 0.9083 \\
\hline & Streams/Lakes & 5484 & 707 & 4117 & 110 & 562 & 541 & 6357 & 86,431 & 29 & 15 & 15 & 104,368 & 0.828137 \\
\hline & Coastal Wetlands & 653 & 1 & 120 & 23 & 32 & 102 & 300 & 37 & 213,438 & 133 & 1930 & 216,769 & 0.984633 \\
\hline & Beach/Barren Lands & 110 & 2 & 160 & 4 & 29 & 22 & 35 & 8 & 696 & 4175 & 662 & 5903 & 0.707267 \\
\hline & Bay/Ocean Water & 1132 & 4 & 145 & 0 & 58 & 84 & 181 & 9 & 907 & 40 & 245,910 & 248,470 & 0.989697 \\
\hline & Total & $1,757,449$ & 588,939 & 837,253 & 318,570 & 370,844 & 137,281 & 856,222 & 106,920 & 216,514 & 4680 & 250,116 & $5,444,788$ & \\
\hline & Producer's accuracy & 0.92497 & 0.9144 & 0.8429 & 0.95869 & 0.9026 & 0.73484 & 0.90681 & 0.8083 & 0.9857 & 0.892 & 0.9831 & & 0.906802 \\
\hline
\end{tabular}


Table 7. Kappa Index of Agreement (KIA) between 2015 classified map and 2015 predicted map for each class including overall Kappa Index.

\begin{tabular}{ccc}
\hline & $\begin{array}{c}\text { Using Classified Land Cover } \\
\text { in 2015 as the Reference }\end{array}$ & $\begin{array}{c}\text { Using Predicted Land Cover } \\
\text { in 2015 as the Reference }\end{array}$ \\
\hline Category & KIA & KIA \\
\hline Urban/Developed Lands & 0.9032 & 0.9094 \\
Farmlands & 0.9032 & 0.9093 \\
Deciduous Forest & 0.83 & 0.8291 \\
Coniferous Forest & 0.9711 & 0.9573 \\
Mixed Forest & 0.8911 & 0.8989 \\
Brush/Grasslands & 0.7725 & 0.7314 \\
Interior Wetlands & 0.8999 & 0.8984 \\
Streams/Lakes & 0.8221 & 0.803 \\
Coastal Wetlands & 0.9842 & 0.9855 \\
Beach/Barren Lands & 0.704 & 0.8894 \\
Bay/Ocean Water & 0.9887 & 0.9815 \\
\hline \multicolumn{2}{c}{ Overall Kappa: 0.9321} \\
\hline
\end{tabular}

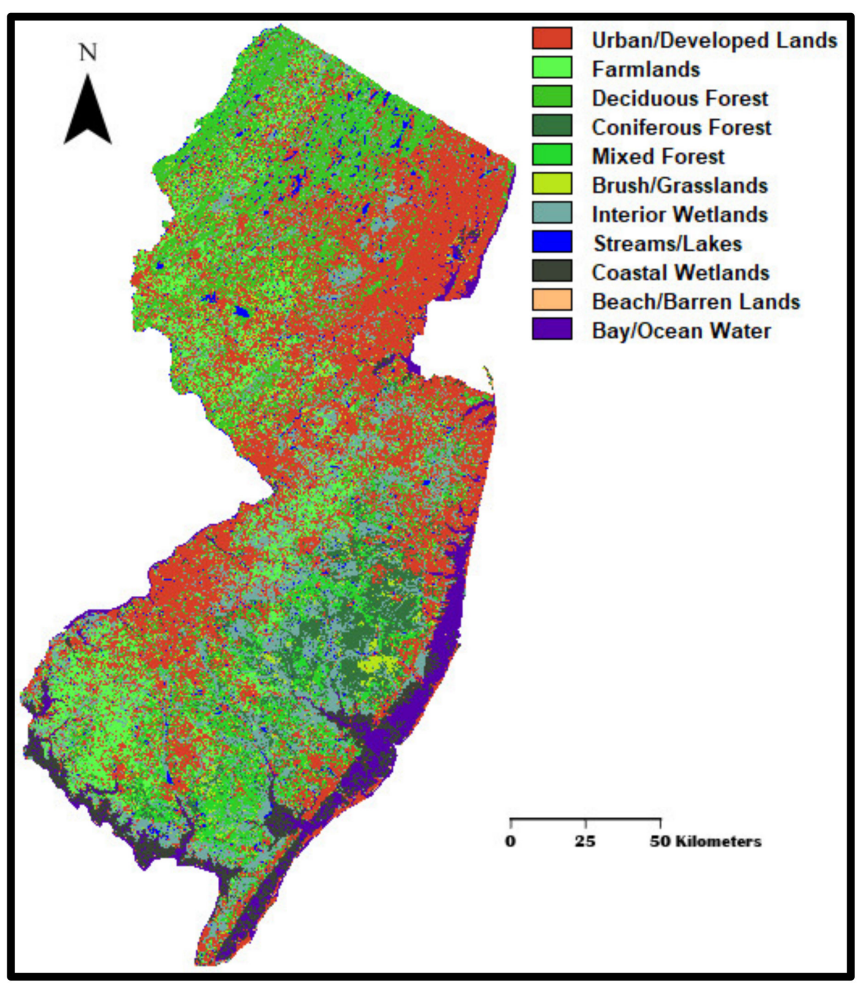

Figure 16. Predicted New Jersey land cover in 2100.

As noted in our analysis of the change from 2007-2012, land cover changes are scattered in small areas across the state and we further analyzed the changes using landscape indices to examine how the changes will reflect in landscape characteristics. Landscape metrics were calculated using a 7-by-7 cell-size window. The landscape texture analysis showed that the projected landscape will likely be identical to the 2012 landscape in terms of fragmentation and dominance with a slight decrease in relative richness and diversity in landscape types for the entire state (Table 8). 


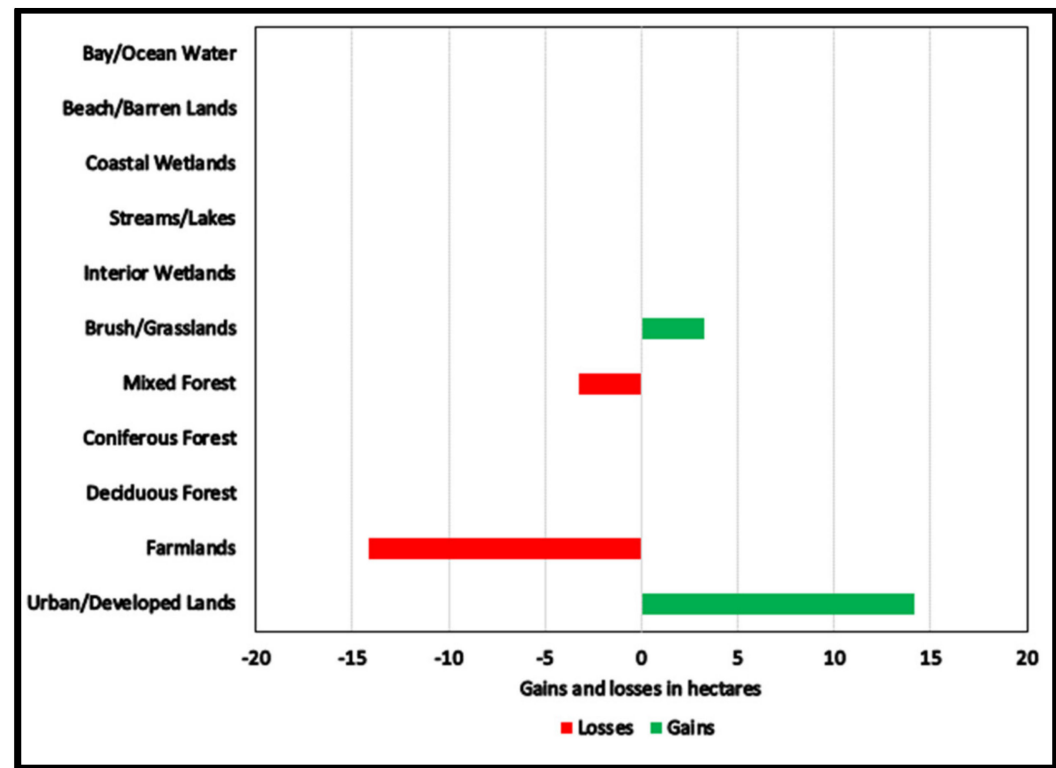

Figure 17. Gains and losses by each class in New Jersey from 2012 to 2100.

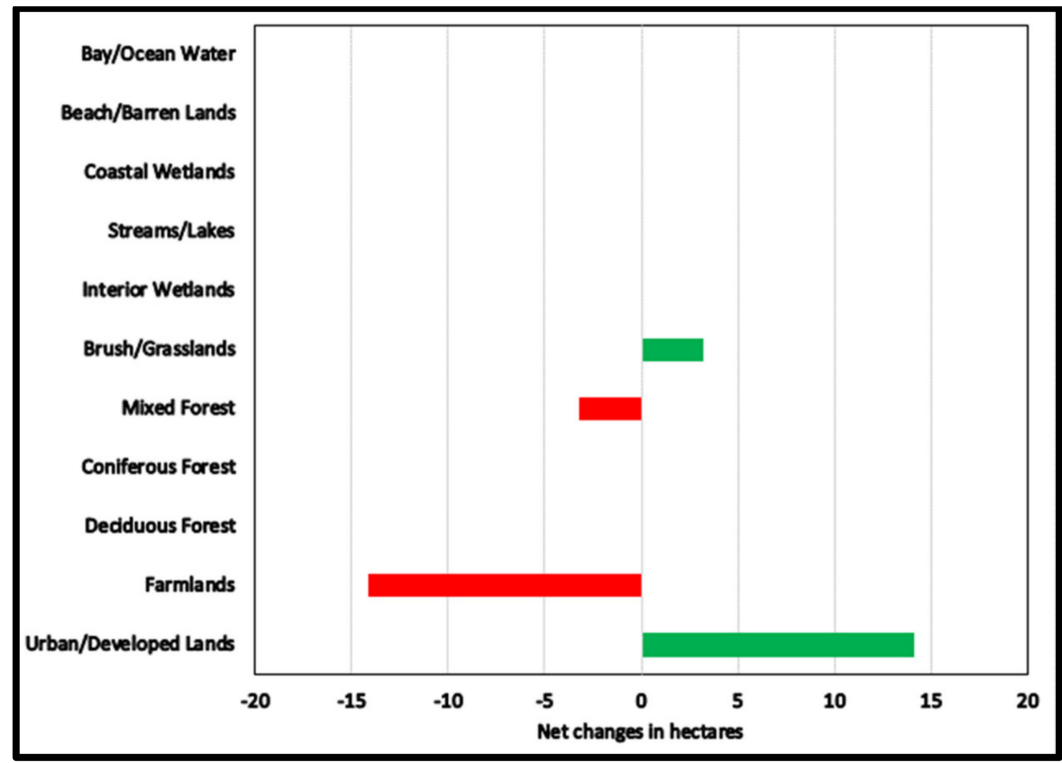

Figure 18. Net change within each class in New Jersey from 2012 to 2100 . The net change for each class was calculated by subtracting the gains from losses based on results from Figure 17. If the gains were higher than the losses, results were positive (green color) otherwise results were negative (red color).

Table 8. Comparison of landscape metrics in 2012 and 2100.

\begin{tabular}{|c|c|c|c|c|c|c|c|c|}
\hline & \multicolumn{4}{|c|}{ LULC in 2112} & \multicolumn{4}{|c|}{ LULC in 2100} \\
\hline & Mean & Minimum & Maximum & Standard Deviation & Mean & Minimum & Maximum & Standard Deviation \\
\hline Fragmentation & 0.027 & 0 & 0.5 & 0.034 & 0.027 & 0 & 0.5 & 0.034 \\
\hline Dominance $\left(D_{o}\right)$ & 0.189 & -0.311 & 1.355 & 0.252 & 0.189 & -0.311 & 1.355 & 0.251 \\
\hline Relative richness & 19.282 & 8.333 & 83.333 & 13.761 & 19.257 & 8.333 & 83.333 & 13.689 \\
\hline Diversity $(H)$ & 0.413 & 0 & 2.156 & 0.508 & 0.413 & 0 & 2.156 & 0.507 \\
\hline
\end{tabular}




\section{Discussion and Conclusions}

Our results from the analysis of 2007-2012 LULC change show that the rate of change in New Jersey in this five-year period is rather small considering the size of our study area. Only two classes had notable spatial expansions. They include urban/developed lands and mixed forest. In many developing countries, such as Kenya or Nepal, the rate is much higher [22,26]. This could be due to differences in both the urbanization stage and LULC management practices. New Jersey is one of the most urbanized states in the United States with much of its land already having been developed by the 2007-2012 study period. Furthermore, several administrative structures were put in place to manage the land that limit further development, which is not the case in many developing countries.

In other parts of the world, the rate of LULC change can be extensive. This is especially true in Africa where the population growth rate and the rate of urbanization are very high [63]. As one of the leading causes of accelerated deforestation, the shifting cultivation farming system is another contributing factor to rapid LULC change [64]. In addition, the dependency on fuelwood harvested from forests and woodlands have drastically altered the spatial extent of these natural resources and led to faster LULC change $[65,66]$. Finally, land use in Sub-Saharan Africa is poorly implemented and generally a source of conflicts resulting in unpredictable LULC changes $[67,68]$.

In New Jersey, the office of Land Use Management administers programs that protect and enhance New Jersey's environment through the implementation of state land use regulations, regional land use planning, coastal resource management and funds projects that result in improvements to the quality of the state's environment [69]. It strives to balance responsible land development and protection of New Jersey's valuable natural resources and recognizes both the environmental limits and opportunities for growth Sustainable community planning entails designing various elements in a way that will meet the needs of the present in an equitable manner without compromising the ability of future generations to meet their own needs [70]. A series of steps are set up when an individual or group of individuals decide to acquire a site [71]. These steps may slow down the acquisition process or may stop it completely. We believe that the existence of the office and the acquisition steps are some of the main reasons of the slow rate of LULC change.

Additionally, two other reasons may explain the slow pace of change. One of them is the slowdown of urban expansion. Gentrification is the process of bringing new residents of a higher socioeconomic status into a low-income neighborhood [72]. The consequence of such a policy is that urban land sprawling into a natural environment is very limited. As such, LULC change is minimal or not changing at all. A previous study has also found that in the northeastern United States, the same taxa that made up the precolonial forest still comprise the forest today [73]. The other reason is that numerous state forest parks are scattered throughout New Jersey that are unlikely to be changed to another type of land use.

It is important to note that the model captured changes and the drivers of changes in the five-year period from 2007 to 2012 but did not capture other indirect changes, such as climate change and invasive species that will inevitably have a significant impact on diversity at the species and ecosystem levels during the next century. Our model showed a net decrease in farmland, as well as coniferous and deciduous forests, but an expansion of the mixed forest (with both conifers and deciduous trees). The direct causes of these trends include the abandonment of farms and rapid rural development and urban expansion into the New Jersey Pine Barrens and deciduous forest areas in the northern region of the state [74]. In fact, between 2001 and 2016, New Jersey lost 8.6\% of its farmland to urban and suburban uses [75]. The increase in mixed forests is likely a resultant succession from abandoned farmland or a shift in forest-cover-type driven by succession [76]. In addition, some insect pests that are common in New Jersey, such as hemlock wooly adelgid, southern pine beetle and eastern pin looper, target only conifers and may result in a shift from coniferous forests towards mixed-tree forests [77]. 
Our prediction from 2012 to 2100 shows that any increase in the mixed-forest cover is short-lived, and there will be an overall decrease in this habitat type, but an increase in brush/grassland. While our model did not incorporate specific environmental factors that will likely affect habitats throughout the state in the next century, we are able to make assumptions based on conditions that existed during the five-year period from 2007 to 2012. For example, invasive insects have become more prevalent in the past few decades, causing extensive loss of many trees, including hardwoods, such as ash and chestnut, and conifers, including hemlock and pine [78,79]. Simultaneously, invasive plants, such as Russian olive, that have taken over many abandoned farms in New Jersey have the ability to establish quickly, prohibiting tree seedlings from becoming rooted and preventing succession. The impact of invasive species on forest establishment and growth is a global threat to biodiversity and may be the primary reason why we see an increase in brush habitat in our model, but a loss of forest cover.

Another important factor that will be intricately linked to ecological shifts that will inevitably occur across the landscape is climate change [80]. For example, while the forests and savannas of the Pine Barrens have evolved with frequent, low-intensity fire and dry conditions, the Atlantic white cedar swamps of that region are sensitive to the hotter and drier conditions, as well as saltwater inundation associated with climate change. Similarly, the deciduous and mixed forests in New Jersey will be very susceptible to damage caused by changes in temperature and precipitation associated with climate change [81-83].

We used a MLP-Markov chain model to predict the future LULC. We predicted the 2015 LULC to validate our model, and it showed high accuracy. It was based on the assumption that the conditions that prevailed in 2012 will continue the same way in the future. Many studies have used similar models to predict short-term LULC change, as there are not many other variables likely to impede in a short period. When projecting a long-term situation, many other unexpected variables will likely interfere. From 2012 to 2100 , factors, such as climate change, will likely completely change the environment in New Jersey $[80,84]$. In addition, the political environment may change within the state and the entire country that may affect the trajectory of future LULC.

We hope that a similar study will be undertaken in other states in the United States of America. We expect that results may not be the same as in New Jersey. Each state has its own land-use laws that are likely to be different from New Jersey laws [85]. Some states are experiencing higher immigration rates of the population, while others are experiencing out-migration [86]. Additionally, some states are relying on logging as a major contributor to their economy [87]. Such situations may have some consequences on LULC changes.

Author Contributions: Conceptualization, K.I.N.; methodology, K.I.N.; software, K.I.N.; validation, K.I.N., F.Q. and D.J.S.; formal analysis, K.I.N. and F.Q.; writing—original draft preparation, K.I.N.; writing-review and editing, K.I.N., F.Q. and D.J.S.; visualization, K.I.N.; supervision, K.I.N. All authors have read and agreed to the published version of the manuscript.

Funding: This research received no external funding.

Data Availability Statement: Publicly available datasets were analyzed in this study. This data can be found here: https:/ / gisdata-njdep.opendata.arcgis.com/ (accessed on 1 August 2021).

Acknowledgments: We would like to thank the School of Environmental and Sustainability Sciences for the software used in this study.

Conflicts of Interest: The authors declare no conflict of interest. 


\section{Appendix A}

Table A1. Original LULC Classes and reclassified LULC classes.

\begin{tabular}{|c|c|}
\hline Original LULC Classes & Reclassified LULC Classes \\
\hline Residential, High Density or Multiple Dwelling & Urban/Developed Lands \\
\hline Residential, Single Unit, Medium Density & Urban/Developed Lands \\
\hline Residential, Single Unit, Low Density & Urban/Developed Lands \\
\hline Residential, Rural, Single Unit & Urban/Developed Lands \\
\hline Mixed Residential & Urban/Developed Lands \\
\hline Commercial/Services & Urban/Developed Lands \\
\hline Military Installations & Urban/Developed Lands \\
\hline No Longer Military & Urban/Developed Lands \\
\hline Industrial & Urban/Developed Lands \\
\hline Transportation/Communication/Utilities & Urban/Developed Lands \\
\hline Major Roadway & Urban/Developed Lands \\
\hline Mixed Transportation Corridor Overlap Area & Urban/Developed Lands \\
\hline Bridge Over Water & Urban/Developed Lands \\
\hline Railroads & Urban/Developed Lands \\
\hline Airport Facilities & Urban/Developed Lands \\
\hline Wetland Rights-of-Way & Interior Wetlands \\
\hline Upland Rights-of-Way Developed & Urban/Developed Lands \\
\hline Upland Rights-of-Way Undeveloped & Urban/Developed Lands \\
\hline Stormwater Basin & Urban/Developed Lands \\
\hline Industrial and Commercial Complexes & Urban/Developed Lands \\
\hline Mixed Urban or Built-Up Land & Urban/Developed Lands \\
\hline Other Urban or Built-Up Land & Urban/Developed Lands \\
\hline Cemetery & Urban/Developed Lands \\
\hline Cemetery on Wetland & Urban/Developed Lands \\
\hline Phragmites Dominate Urban Area & Urban/Developed Lands \\
\hline Managed Wetland in Maintained Lawn Greenspace & Urban/Developed Lands \\
\hline Recreational Land & Urban/Developed Lands \\
\hline Athletic Fields (Schools) & Urban/Developed Lands \\
\hline Stadium, Theaters, Cultural Centers and Zoos & Urban/Developed Lands \\
\hline Managed Wetland in Built-Up Maintained Rec Area & Interior Wetlands \\
\hline Cropland and Pastureland & Farmlands \\
\hline Agricultural Wetlands (Modified) & Farmlands \\
\hline Former Agricultural Wetland (Becoming Shrubby, Not Built-Up) & Interior Wetlands \\
\hline Orchards/Vineyards/Nurseries/Horticultural Areas & Farmlands \\
\hline Confined Feeding Operations & Farmlands \\
\hline Other Agriculture & Farmlands \\
\hline Deciduous Forest (10-50\% Crown Closure) & Deciduous Forest \\
\hline Deciduous Forest (>50\% Crown Closure) & Deciduous Forest \\
\hline Coniferous Forest (10-50\% Crown Closure) & Coniferous Forest \\
\hline Coniferous Forest ( $>50 \%$ Crown Closure) & Coniferous Forest \\
\hline Plantation & Farmlands \\
\hline Mixed Forest ( $>50 \%$ Coniferous with $10-50 \%$ Crown Closure) & Mixed Forest \\
\hline Mixed Forest ( $>50 \%$ Coniferous with $>50 \%$ Crown Closure) & Mixed Forest \\
\hline Mixed Forest ( $>50 \%$ Deciduous with $10-50 \%$ Crown Closure) & Mixed Forest \\
\hline Mixed Forest ( $>50 \%$ Deciduous with $>50 \%$ Crown Closure) & Mixed Forest \\
\hline Old Field $(<25 \%$ Brush Covered $)$ & Mixed Forest \\
\hline Phragmites Dominate Old Field & Brush/Grasslands \\
\hline Deciduous Brush/Shrubland & Brush/Grasslands \\
\hline Coniferous Brush/Shrubland & Brush/Grasslands \\
\hline Mixed Deciduous/Coniferous Brush/Shrubland & Brush/Grasslands \\
\hline Severe Burned Upland Vegetation & Brush/Grasslands \\
\hline Streams and Canals & Streams/Lakes \\
\hline Exposed Flats & Streams/Lakes \\
\hline Natural Lakes & Streams/Lakes \\
\hline Artificial Lakes & Streams/Lakes \\
\hline
\end{tabular}


Table A1. Cont.

\begin{tabular}{|c|c|}
\hline Original LULC Classes & Reclassified LULC Classes \\
\hline Tidal Rivers, Inland Bays and Other Tidal Waters & Bay/Ocean Water \\
\hline Open Tidal Bays & Bay/Ocean Water \\
\hline Tidal Mud Flat & Bay/Ocean Water \\
\hline Dredged Lagoon & Bay/Ocean Water \\
\hline Atlantic Ocean & Bay/Ocean Water \\
\hline Saline Marsh (Low Marsh) & Coastal Wetlands \\
\hline Saline Marsh (High Marsh) & Coastal Wetlands \\
\hline Freshwater Tidal Marshes & Coastal Wetlands \\
\hline Vegetated Dune Communities & Brush/Grasslands \\
\hline Phragmites Dominate Coastal Wetlands & Coastal Wetlands \\
\hline Deciduous Wooded Wetlands & Interior Wetlands \\
\hline Coniferous Wooded Wetlands & Interior Wetlands \\
\hline Atlantic White Cedar Wetlands & Interior Wetlands \\
\hline Deciduous Scrub/Shrub Wetlands & Interior Wetlands \\
\hline Coniferous Scrub/Shrub Wetlands & Interior Wetlands \\
\hline Mixed Scrub/Shrub Wetlands (Deciduous Dom.) & Interior Wetlands \\
\hline Mixed Scrub/Shrub Wetlands (Coniferous Dom.) & Interior Wetlands \\
\hline Herbaceous Wetlands & Interior Wetlands \\
\hline Phragmites Dominate Interior Wetlands & Interior Wetlands \\
\hline Mixed Wooded Wetlands (Deciduous Dom.) & Interior Wetlands \\
\hline Mixed Wooded Wetlands (Coniferous Dom.) & Interior Wetlands \\
\hline Unvegetated Flats & Interior Wetlands \\
\hline Severe Burned Wetland Vegetation & Interior Wetlands \\
\hline Beaches & Beach/Barren Lands \\
\hline Bare Exposed Rock, Rock Slides, Etc. & Beach/Barren Lands \\
\hline Extractive Mining & Urban/Developed Lands \\
\hline Altered Lands & Urban/Developed Lands \\
\hline Disturbed Wetlands (Modified) & Interior Wetlands \\
\hline Disturbed Tidal Wetlands & Coastal Wetlands \\
\hline Transitional Areas & Beach/Barren Lands \\
\hline Undifferentiated Barren Lands & Beach/Barren Lands \\
\hline
\end{tabular}

\section{References}

1. Fisher, P.; Comber, A.; Wadsworth, R. Land Use and Land Cover: Contradiction or Complement. In Re-Presenting GIS; Fisher, P., Unwin, D.J., Eds.; John Wiley and Sons Ltd.: Leicester, UK, 2005.

2. Di Gregorio, A.; Jansen, L.J.M. Land Cover Classification System-Classification Concepts and User Manual; Environment and Natural Resources Series; Food and Agriculture Organization of the United Nations: Rome, Italy, 2005.

3. National Oceanic and Atmospheric Administration (NOAA). What Is the Difference between Land Cover and Land Use? Available online: https:/ / oceanservice.noaa.gov/facts/lclu.html (accessed on 13 August 2021).

4. Latham, J.S.; He, C.; Alinovi, L.; DiGregorio, A.; Kalensky, Z. FAO Methodologies for Land Cover Classification and Mapping. In Linking People, Place, and Policy: A GIScience Approach; Walsh, S.J., Crews-Meyer, K.A., Eds.; Springer: Boston, MA, USA, 2002; pp. 283-316. [CrossRef]

5. Meyer, W.B.; Turner, B.L. Human Population Growth and Global Land-Use/Cover Change. Annu. Rev. Ecol. Syst. 1992, 2, 39-61. [CrossRef]

6. Uvsh, D.; Gehlbach, S.; Potapov, P.V.; Munteanu, C.; Bragina, E.V.; Radeloff, V.C. Correlates of Forest-Cover Change in European Russia, 1989-2012. Land Use Policy 2020, 96, 104648. [CrossRef]

7. Bracchetti, L.; Carotenuto, L.; Catorci, A. Land-Cover Changes in a Remote Area of Central Apennines (Italy) and Management Directions. Landsc. Urban Plan. 2012, 104, 157-170. [CrossRef]

8. Crews-Meyer, K.A. Agricultural Landscape Change and Stability in Northeast Thailand: Historical Patch-Level Analysis. Agric. Ecosyst. Environ. 2004, 101, 155-169. [CrossRef]

9. Zheng, Z.; Wu, Z.; Chen, Y.; Yang, Z.; Marinello, F. Exploration of Eco-Environment and Urbanization Changes in Coastal Zones: A Case Study in China over the Past 20 Years. Ecol. Indic. 2020, 119, 106847. [CrossRef]

10. Jasinski, E.; Morton, D.; DeFries, R.; Shimabukuro, Y.; Anderson, L.; Hansen, M. Physical Landscape Correlates of the Expansion of Mechanized Agriculture in Mato Grosso, Brazil. Earth Interact. 2005, 9, 1-18. [CrossRef]

11. Hailu, A.; Mammo, S.; Kidane, M. Dynamics of Land Use, Land Cover Change Trend and Its Drivers in Jimma Geneti District, Western Ethiopia. Land Use Policy 2020, 99, 105011. [CrossRef] 
12. Abd El-Kawy, O.R.; El-Kawy, O.R.A.; Rød, J.K.; Ismail, H.A.; Suliman, A.S. Land Use and Land Cover Change Detection in the Western Nile Delta of Egypt Using Remote Sensing Data. Appl. Geogr. 2011, 31, 483-494. [CrossRef]

13. Vågen, T.-G. Remote Sensing of Complex Land Use Change Trajectories-A Case Study from the Highlands of Madagascar. Agric. Ecosyst. Environ. 2006, 115, 219-228. [CrossRef]

14. Kindu, M.; Schneider, T.; Teketay, D.; Knoke, T. Land Use/Land Cover Change Analysis Using Object-Based Classification Approach in Munessa-Shashemene Landscape of the Ethiopian Highlands. Remote Sens. 2013, 5, 2411. [CrossRef]

15. Demissie, F.; Yeshitila, K.; Kindu, M.; Schneider, T. Land Use/Land Cover Changes and Their Causes in Libokemkem District of South Gonder, Ethiopia. Remote Sens. Appl. Soc. Environ. 2017, 8, 224-230. [CrossRef]

16. Asenso Barnieh, B.; Jia, L.; Menenti, M.; Zhou, J.; Zeng, Y. Mapping Land Use Land Cover Transitions at Different Spatiotemporal Scales in West Africa. Sustainability 2020, 12, 8565. [CrossRef]

17. Chimi, C.; Tenzin, J.; Cheki, T. Assessment of Land Use/Cover Change and Urban Expansion Using Remote Sensing and GIS: A Case Study in Phuentsholing Municipality, Chukha, Bhutan. Int. J. Energy Environ. Sci. 2017, 2, 127-135. [CrossRef]

18. Elmahdy, S.; Mohamed, M.; Ali, T. Land Use/Land Cover Changes Impact on Groundwater Level and Quality in the Northern Part of the United Arab Emirates. Remote Sens. 2020, 12, 1715. [CrossRef]

19. Montalván-Burbano, N.; Velastegui-Montoya, A.; Gurumendi-Noriega, M.; Morante-Carballo, F.; Adami, M. Worldwide Research on Land Use and Land Cover in the Amazon Region. Sustainability 2021, 13, 6039. [CrossRef]

20. Talukdar, S.; Singha, P.; Mahato, S.; Shahfahad; Pal, S.; Liou, Y.-A.; Rahman, A. Land-Use Land-Cover Classification by Machine Learning Classifiers for Satellite Observations-A Review. Remote Sens. 2020, 12, 1135. [CrossRef]

21. Maxwell, A.E.; Warner, T.A.; Fang, F. Implementation of Machine-Learning Classification in Remote Sensing: An Applied Review. Int. J. Remote. Sens. 2018, 39, 2784-2817. [CrossRef]

22. Mubea, K.W.; Ngigi, T.G.; Mundia, C.N. Assessing Application of Markov Chain Analysis in Predicting Land Cover Change: A Case Study of Nakuru Municipality. J. Agric. Sci. Technol. 2011, 12, 182-188.

23. Islam, M.S.; Ahmed, R. Land Use Change Prediction in Dhaka City Using Gis Aided Markov Chain Modeling. J. Life Earth Sci. 2011, 6, 81-89. [CrossRef]

24. Iacono, M.; Levinson, D.; El-Geneidy, A.; Wasfi, R. A Markov Chain Model of Land Use Change. TeMA—J. Land Use Mobil. Environ. 2015, 8, 263-276. [CrossRef]

25. Hua, A.K. Application Of CA-Markov Model and Land Use/Land Cover Changes in Malacca River Watershed, Malaysia. Appl. Ecol. Environ. Res. 2017, 15, 605-622. [CrossRef]

26. Rimal, B.; Zhang, L.; Keshtkar, H.; Wang, N.; Lin, Y. Monitoring and Modeling of Spatiotemporal Urban Expansion and Land-Use/Land-Cover Change Using Integrated Markov Chain Cellular Automata Model. ISPRS Int. J. Geo-Inf. 2017, 6, 288. [CrossRef]

27. Surabuddin Mondal, M.; Sharma, N.; Kappas, M.; Garg, P.K. CA Markov Modeling of Land Use Land Cover Dynamics And Sensitivity Analysis To Identify Sensitive Parameter(S). Int. Arch. Photogramm. Remote Sens. Spatial Inf. Sci. 2019, XLII-2/W13, 723-729. [CrossRef]

28. Lai, Y.; Huang, G.; Chen, S.; Lin, S.; Lin, W.; Lyu, J. Land Use Dynamics and Optimization from 2000 to 2020 in East Guangdong Province, China. Sustainability 2021, 13, 3473. [CrossRef]

29. Eastman, J.R.; He, J. A Regression-Based Procedure for Markov Transition Probability Estimation in Land Change Modeling. Land 2020, 9, 407. [CrossRef]

30. Guo, A.; Zhang, Y.; Hao, Q. Monitoring and Simulation of Dynamic Spatiotemporal Land Use/Cover Changes. Complexity 2020, 2020, e3547323. [CrossRef]

31. Shen, L.; Li, J.; Wheate, R.; Yin, J.; Paul, S. Multi-Layer Perceptron Neural Network and Markov Chain Based Geospatial Analysis of Land Use and Land Cover Change. J. Environ. Inform. Lett. 2020, 3, 29-39. [CrossRef]

32. Dadhich, P.N.; Hanaoka, S. Markov Method Integration with Multi-Layer Perceptron Classifier for Simulation of Urban Growth of Jaipur City. In Proceedings of the 6th International Conference on Remote Sensing, Iwate, Japan, 4-6 October 2010; pp. 118-123.

33. Iizuka, K.; Johnson, B.A.; Onishi, A.; Magcale-Macandog, D.B.; Endo, I.; Bragais, M. Modeling Future Urban Sprawl and Landscape Change in the Laguna de Bay Area, Philippines. Land 2017, 6, 26. [CrossRef]

34. Pereira e Silva, L.; Xavier, A.P.C.; da Silva, R.M.; Santos, C.A.G. Modeling Land Cover Change Based on an Artificial Neural Network for a Semiarid River Basin in Northeastern Brazil. Glob. Ecol. Conserv. 2020, 21, e00811. [CrossRef]

35. Ozturk, D. Urban Growth Simulation of Atakum (Samsun, Turkey) Using Cellular Automata-Markov Chain and Multi-Layer Perceptron-Markov Chain Models. Remote Sens. 2015, 7, 5918-5950. [CrossRef]

36. The Geography of New Jersey. Available online: https://www.netstate.com/states/geography/nj_geography.htm (accessed on 28 July 2021).

37. Wacker, P.O. New Jersey State, United States. Available online: https:/ / www.britannica.com/place/New-Jersey (accessed on 28 July 2021).

38. Salisbury, R.D. The Physical Geography of New Jersey; Geological Survey of New Jersey: Trenton, NJ, USA, 1808 ; p. 400.

39. New Jersey-New World Encyclopedia. Available online: https://www.newworldencyclopedia.org/entry/New_Jersey (accessed on 28 July 2021). 
40. Zimmer, D.M. What New Jersey 2020 Census Results Reveal About State's Population. Available online: https:/ / www.northjersey. com/story/news/new-jersey/2021/08/12/nj-population-2021-by-county-growth-2020-census-results/8113856002/ (accessed on 19 September 2021).

41. Population Density in the U.S., by State 2020. Available online: https://www.statista.com/statistics/183588/population-densityin-the-federal-states-of-the-us / (accessed on 30 July 2021).

42. List of U.S. States by Population Density. 2021. Available online: https://simple.wikipedia.org/wiki/List_of_U.S._states_by_ population_density (accessed on 30 July 2021).

43. US Census Bureau. State Population Totals: 2010-2020. Available online: https://www.census.gov/programs-surveys/ popest/technical-documentation/research/evaluation-estimates/2020-evaluation-estimates/2010s-state-total.html (accessed on 27 July 2021).

44. World Population Review. Population of Counties in New Jersey. 2021. Available online: https://worldpopulationreview.com/ us-counties/states/nj (accessed on 31 July 2021).

45. New Jersey Department of Labor and Workforce Development. 2020 Population Density: New Jersey Counties. 2021. Available online: https:/ / www.nj.gov/labor/lpa/content/maps/Popden.pdf (accessed on 1 August 2021).

46. New Jersey Department of Environmental Protection. 2012 Land Use/Land Cover Update and Impervious Surface Mapping Project. Available online: https://www.nj.gov/dep/gis/digidownload/metadata/lulc12/update2012.html (accessed on 25 August 2021).

47. Esri. 2D, 3D \& 4D GIS Mapping Software I ArcGIS Pro. Available online: https://www.esri.com/en-us/arcgis/products/arcgispro/overview (accessed on 14 October 2021).

48. Clark University. TerrSet 2020 Software Features. Available online: https:/ / clarklabs.org/ (accessed on 7 August 2021).

49. Orrù, P.F.; Zoccheddu, A.; Sassu, L.; Mattia, C.; Cozza, R.; Arena, S. Machine Learning Approach Using MLP and SVM Algorithms for the Fault Prediction of a Centrifugal Pump in the Oil and Gas Industry. Sustainability 2020, 12, 4776. [CrossRef]

50. Hastie, T.; Tibshirani, R.; Friedman, J. The Elements of Statistical Learning: Data Mining, Inference, and Prediction, 2nd ed.; Springer Series in Statistics; Springer: New Yok, NY, USA, 2017; Available online: https:/ / web.stanford.edu/ \{\}hastie/ElemStatLearn/ printings/ESLII_print12_toc.pdf (accessed on 17 August 2021).

51. Kityuttachai, K.; Tripathi, N.K.; Tipdecho, T.; Shrestha, R. CA-Markov Analysis of Constrained Coastal Urban Growth Modeling: Hua Hin Seaside City, Thailand. Sustainability 2013, 5, 1480-1500. [CrossRef]

52. Subedi, P.; Subedi, K.; Thapa, B. Application of a Hybrid Cellular Automaton-Markov (CA-Markov) Model in Land-Use Change Prediction: A Case Study of Saddle Creek Drainage Basin, Florida. Appl. Ecol. Environ. Sci. 2013, 1, 126-132. [CrossRef]

53. Pontius, R.G. Quantification Error Versus Location Error in Comparison of Categorical Maps. Photogramm. Remote Sens. 2000, 66, 1011-1016.

54. Pontius, R.G. Statistical Methods to Partition Effects of Quantity and Location During Comparison of Categorical Maps at Multiple Resolutions. Photogramm. Eng. Remote 2002, 68, 1041-1049.

55. Pontius Jr, R.G.; Batchu, K. Using the Relative Operating Characteristic to Quantify Certainty in Prediction of Location of Land Cover Change in India. Trans. GIS 2003, 7, 467-484. [CrossRef]

56. Ariza-Lopez, F.J.; Rodriguez-Avi, J.; Alba-Fernandez, M.V. Complete Control of an Observed Confusion Matrix. In Proceedings of the IGARSS 2018-2018 IEEE International Geoscience and Remote Sensing Symposium, Valencia, Spain, 22-27 July 2018; pp. 1222-1225. [CrossRef]

57. Ukrainski, P.; Classification Accuracy Assessment. Confusion Matrix Method. 50 North IGIS Blog from Ukraine. 2016. Available online: http://www.50northspatial.org/classification-accuracy-assessment-confusion-matrix-method/ (accessed on 9 August 2021).

58. Lewis, H.G.; Brown, M. A Generalized Confusion Matrix for Assessing Area Estimates from Remotely Sensed Data. Int. J. Remote Sens. 2001, 22, 3223-3235. [CrossRef]

59. Visa, S.; Ramsay, B.; Ralescu, A.; Knaap, E. Confusion Matrix-Based Feature Selection. In Proceedings of the 22nd Midwest Artificial Intelligence and Cognitive Science Conference 2011, Cincinnati, OH, USA, 16-17 April 2011; Volume 710, p. 127.

60. Monmonier, M. Measures of Pattern Complexity for Choropleth Maps. Cartogr. Geogr. Inf. Sci. 1974, 1, 159-169. [CrossRef]

61. Turner, M.G. Landscape Ecology: The Effect of Pattern on Process. Annu. Rev. Ecol. Syst. 1989, 20, 171-197. [CrossRef]

62. Elmes, A.; Alemohammad, H.; Avery, R.; Caylor, K.; Eastman, J.R.; Fishgold, L.; Friedl, M.A.; Jain, M.; Kohli, D.; Laso Bayas, J.C.; et al. Accounting for Training Data Error in Machine Learning Applied to Earth Observations. Remote Sens. 2020, $12,1034$. [CrossRef]

63. Saghir, J.; Santoro, J.; Urbanization in Sub-Saharan Africa: Meeting Challenges by Bridging Stakeholders. Center for Strategic and International Studies. 2018. Available online: https://csis-website-prod.s3.amazonaws.com/s3fs-public/publication/180411 _Saghir_UrbanizationAfrica_Web.pdf (accessed on 19 September 2021).

64. Zhang, Q.; Justice, C.O.; Desanker, P.V. Impacts of Simulated Shifting Cultivation on Deforestation and the Carbon Stocks of the Forests of Central Africa. Agric. Ecosyst. Environ. 2002, 90, 203-209. [CrossRef]

65. Sola, P.; Cerutti, P.O.; Zhou, W.; Gautier, D.; Iiyama, M.; Schure, J.; Chenevoy, A.; Yila, J.; Dufe, V.; Nasi, R.; et al. The Environmental, Socioeconomic, and Health Impacts of Woodfuel Value Chains in Sub-Saharan Africa: A Systematic Map. Environ. Evid. 2017, 6, 4. [CrossRef] 
66. Paré, S.; Söderberg, U.; Sandewall, M.; Ouadba, J.M. Land Use Analysis from Spatial and Field Data Capture in Southern Burkina Faso, West Africa. Agric. Ecosyst. Environ. 2008, 127, 277-285. [CrossRef]

67. Bob, U. Land-related conflicts in Sub-Saharan Africa. Available online: https://www.accord.org.za/ajcr-issues/land-relatedconflicts-in-sub-saharan-africa / (accessed on 19 September 2021).

68. Peters, P.E. Inequality and Social Conflict Over Land in Africa. J. Agrar. Chang. 2004, 4, 269-314. [CrossRef]

69. NJDEP-Division of Land Resource Protection-Home. Available online: https://www.nj.gov/dep/landuse/ (accessed on 19 August 2021).

70. NJDEP I Land Use Management. Available online: https://www.nj.gov/dep/lum/ (accessed on 19 August 2021).

71. NJDEP-Division of Land Use Regulation-Home. Available online: https://www.nj.gov/dep/landuse/process.html (accessed on 19 August 2021).

72. Callinan, S. Gentrification of Two New Jersey Cities. Available online: https://storymaps.arcgis.com/stories/e38e09f5c5a045 abae1571e9b7cb769d (accessed on 19 August 2021).

73. Thompson, J.R.; Carpenter, D.N.; Cogbill, C.V.; Foster, D.R. Four Centuries of Change in Northeastern United States Forests. PLoS ONE 2013, 8, e72540. [CrossRef] [PubMed]

74. Edwards, J.W.; Dachelet, C.A.; Smathers, W.M. A Mobile Aviary to Enhance Translocation Success of Red-Cockaded Woodpeckers. In Proceedings of the 37th Annual Meeting of the Canadian Society of Environmental Biologists; 1997. Available online: https: //www.fs.usda.gov/treesearch/pubs/1959 (accessed on 5 October 2021).

75. Flammia, D. NJ Tops Nation for Addressing the Loss of Farmland. Available online: https://nj1015.com/nj-tops-nation-foraddressing-the-loss-of-farmland/ (accessed on 15 October 2021).

76. Benincà, E.; Ballantine, B.; Ellner, S.; Huisman, J. Species Fluctuations Sustained by a Cyclic Succession at the Edge of Chaos. Proc. Natl. Acad. Sci. USA 2015, 112, 6389-6394. [CrossRef]

77. NJDEP New Jersey Department of Environmental Protection. Forest Health in New Jersey. Available online: https://www.state. nj.us/dep/parksandforests/forest/njfs_forest_health.html (accessed on 15 October 2021).

78. Fallon, S. New Jersey Prepares for Possible Invasion of Tree-Destroying Bug, the Spotted Lanternfly. Available online: https: //www.northjersey.com/story/news/environment/2017/10/08/tree-destroying-bug-on-njs-doorstep/618329001/ (accessed on 27 August 2021).

79. Kent, S.; NJ Advance Media for NJ.com. The 12 Grossest Living Things That are Killing N.J.'s Trees. Available online: https: //www.nj.com/news/2017/05/greatest_threats_to_njs_trees.html (accessed on 15 October 2021).

80. Hayhoe, K.; Wake, C.; Anderson, B.; Liang, X.-Z.; Maurer, E.; Zhu, J.; Bradbury, J.; DeGaetano, A.; Stoner, A.M.; Wuebbles, D. Regional Climate Change Projections for the Northeast USA. Mitig. Adapt. Strateg. Glob. Chang. 2008, 13, 425-436. [CrossRef]

81. The New Jersey Climate Change Resource Center. Climate Change in New Jersey: Impacts and Responses, Rutgers, The State University of New Jersey. 2020. Available online: https:/ / njclimateresourcecenter.rutgers.edu/ (accessed on 5 October 2021).

82. Janowiak, M.K.; D'Amato, A.W.; Swanston, C.W.; Iverson, L.; Thompson, F.R.; Dijak, W.D.; Matthews, S.; Peters, M.P.; Prasad, A.; Fraser, J.S.; et al. New England and Northern New York Forest Ecosystem Vulnerability Assessment and Synthesis: A Report from the New England Climate Change Response Framework Project; NRS-GTR-173; U.S. Department of Agriculture, Forest Service, Northern Research Station: Newtown Square, PA, USA, 2018. [CrossRef]

83. Evans, A.; Mahaffey, A. Restoration and Resilience in New Jersey's Forests; ForesGUILD: Santa Fe, NM, USA, 2014; Available online: https:/ / foreststewardsguild.org/wp-content/uploads/2019/05/New_Jersey.pdf (accessed on 7 October 2021).

84. Ngoy, K.I.; Shebitz, D. Potential Impacts of Climate Change on Areas Suitable to Grow Some Key Crops in New Jersey, USA. Environments 2020, 7, 76. [CrossRef]

85. Environmental Law Institute. Land Use. Available online: https://www.eli.org/keywords/land-use (accessed on 15 October 2021).

86. Cammenga, J. Where Did Americans Move in 2020? 2021. Available online: https://taxfoundation.org/state-migration-trends/ (accessed on 7 October 2021).

87. Loomis, E. Forests and Logging in the United States. Available online: https://oxfordre.com/americanhistory/view/10.1093/ acrefore/9780199329175.001.0001/acrefore-9780199329175-e-188 (accessed on 15 October 2021). [CrossRef] 